\title{
دمسالازنينينيالمياة العلميت
}

فى الأثنلس من خلالكنابهالصلتهي لابن بشكوال

\author{
vos \\ حسنبنيیى الشوكاني \\ كليتا العلور الإنسانتيتجامعتالملكلك خالد \\ أهما - المملكت العريت السعوديتي
}


دور الأزديين في الحياة العلمية فى الأندلس

يوليو 2009

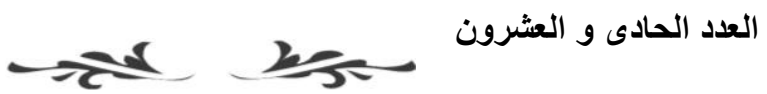




\section{دور الأزديين في الحياة العلمية}

فى الأندلس من خلال كتاب 》الصلة| لابن لابن بشكوال

$$
\text { دكتور }
$$

حسن بن بحيى الشوكاني

كلية العلوم الإنسانية جامعة الملّك خالد الد الدي

أبها- المملكة العربية السعانة جامعة المبية

الحمد الله رب العالمين والصلاة والسلام على النبي الأمين وبعد ..

فمن خلال تتبعي لكتب السير والتراجم الأندلسية، وقراعتي عن مسيرة الحركة

العلمية في الأندلس الإسلامية لاحظت أن للقبائل العربية التي هاجرت من الن

الجزيرة العربية إلى الأندلس - منذ مراح الفتح الإسلامي المبكر لتلك البلاد وما

تلاه من عهود- دور بارز ورئيس في البناء الفكري والتقدم الحضاري الذي إي

شهدته تللك البلاد إبان نوَّهج نور الإسلام فيها، وفت نظري كثرة المنتسبين إلى بـ

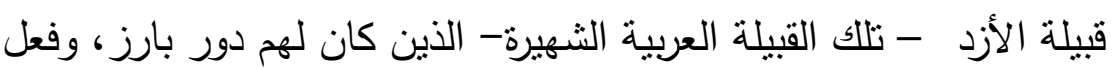
ظاهر، في مسيرة الحركة العلمية في الأندلس، ولذلك رأيت أن أنتبع دور أولئك بلك الأعلام المنتسبين إلى هذه القبيلة وأثرهم في الحياة العلمية ومقدار ما أسهموا به اله في المنتج العلمي في الأندلس ، وأثر ذلك في تقدم وازدهار العلوم والمعارف في الأندلس.

وحرصاً على حصر الموضوع رأيت أن أكتفي بما أورده المؤرخ والفقيه والمحدث الأندلسي أبو القاسم خلف بن عبدالملك المعروف بابن بشكوال والمتوفى المي في سنة ( 578هـ/1182م) في مؤلفه القيم الموسوم الصلة في تاريخ أئمة الأندلس وعلمائهم ومحدثيهم وأدبائهم " ذللك الكتاب الذي يُعد في مقدمة كتب التراجم والسير لعلماء الأندلس • حيث وصل به ابن بشكوال كتاب شيخه وإمامه ومابه

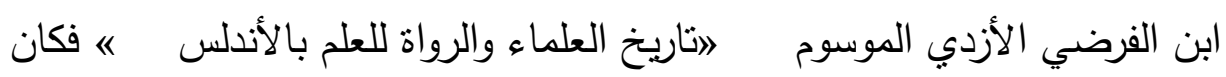
يوليو 2009 
للمؤلفين قصب السبق في رصد الحركة العلمية في الأندلس، وإبراز رموزها ومخرجاتها العلمية.

وكما اقتصر البحث على كتاب 》الصلةه فقد ركز على الأعلام الذين

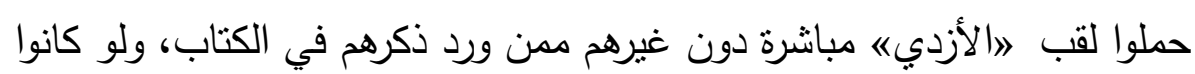

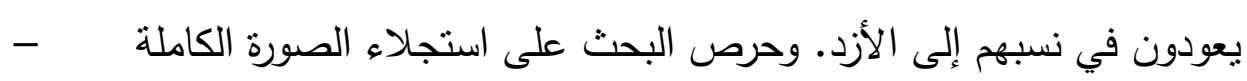

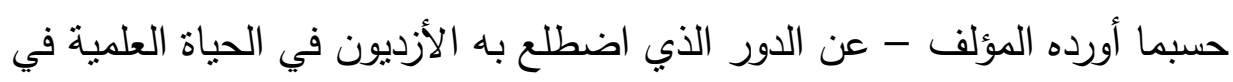

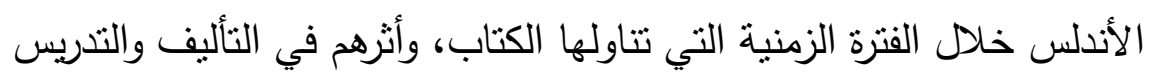

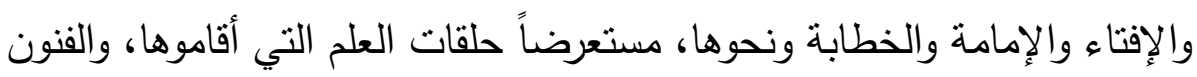

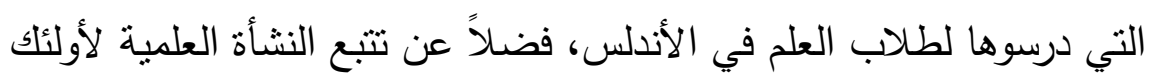

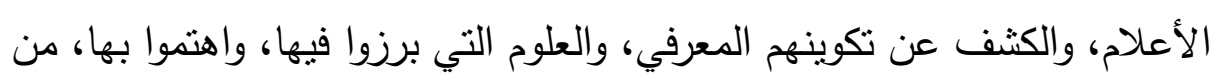

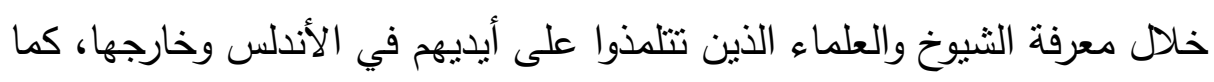

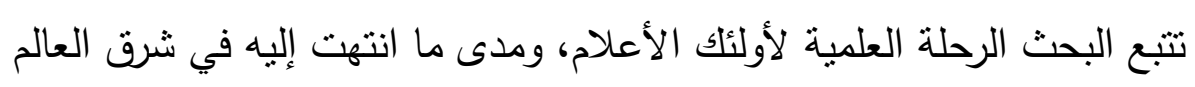

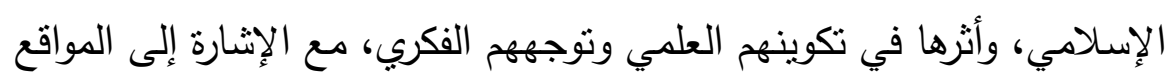

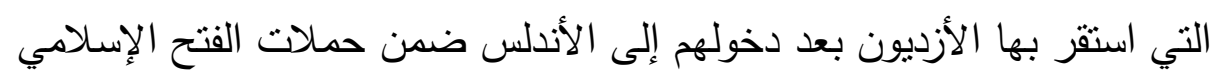
وما تلاها .

ولا شك أن دراسة منل هذا الموضوع تسهم في نسليط الضوء بشكل جلي

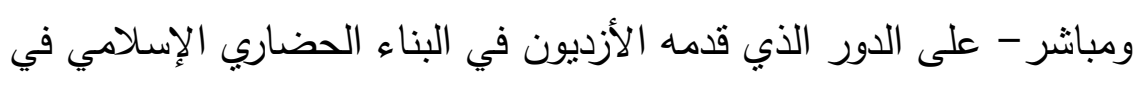
الأندلس، وما حققوه للحركة العلمية بها تدريساً وتصنيفاً وتعليماً.

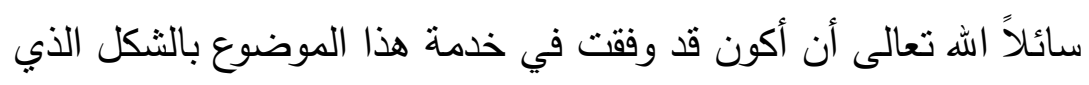

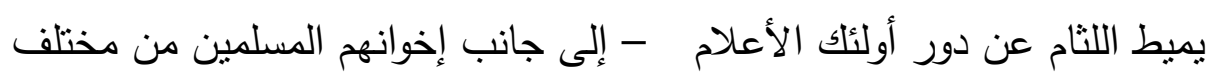
الأعراق والأنساب - في خدمة العلم وأهله.

يوليو 2009

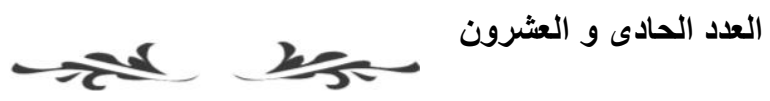




\section{0}

الحمد لله والصلاة والسلام على رسول الله وبعد ..

تمثل قبيلة الأزد أحد الفروع الكبيرة لعرب الجنوب (القحطانبة) ويعود نسبها إلى رستى

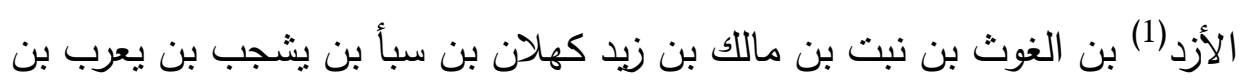

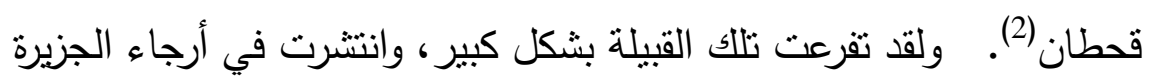

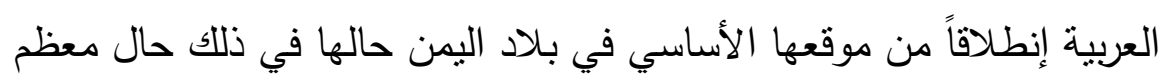
القبائل القحطانية التي هاجرت إلى وسط وشمال الجزيرة العربية وما وراءها وحينما انتشر نور الإسلام في جزيرة العرب كان الأزديون أول المنضمين تحت

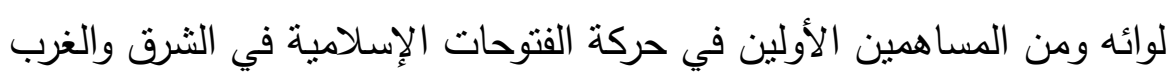
على حدٍ سواء (4).

(1 ) وقيل اسمه 》أُدَده انظر : ابن حزم : جمهرة أنساب العرب ، بيروت، دار الكتب العلمية، 1418هـ -

$$
\text { 1988م، ص 330. }
$$

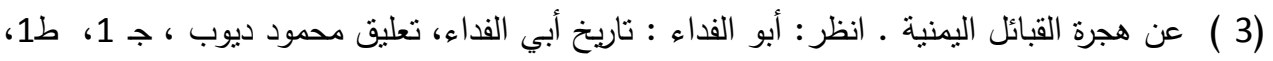

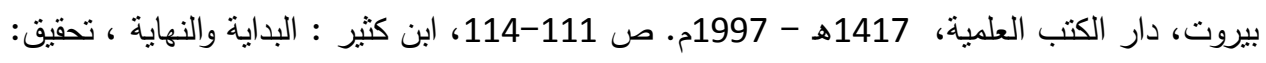

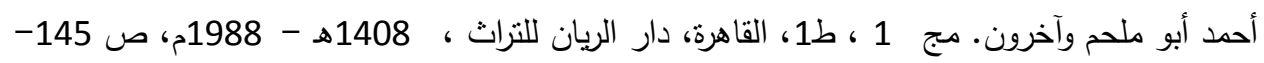

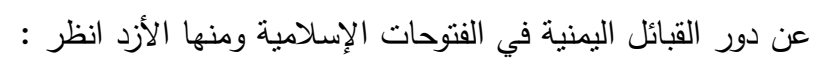

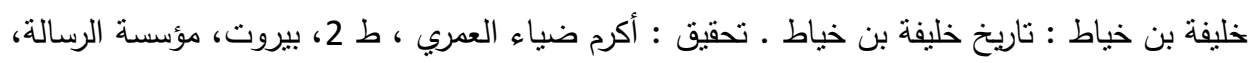

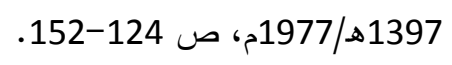

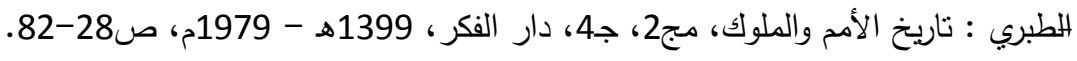

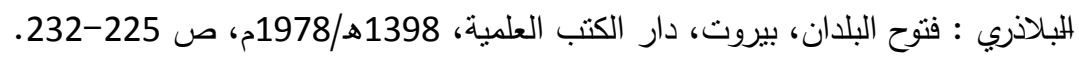
يوليو 2009

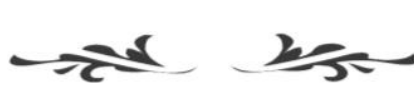

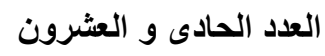


وفي بلاد المغرب استقرت القبائل اليمنية إلى جانب غيرها من القبائل العربية الأخرى التي أسهمت في فتح بلاد المغرب بداءً من برقة ووصولاً إلى بلى شواطىء المحيط الأطلسي في المغرب الأقصى (1).

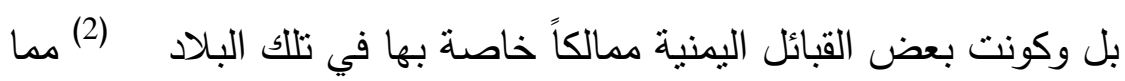
يدل على كثرة وقوة القبائل اليمنية التي انتشرت بعد الفتح الإسلامي في بلاد

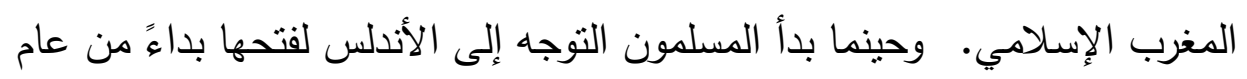

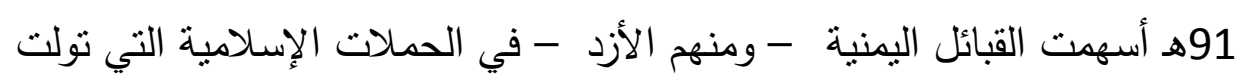
فتح الأندلس، حيث كان أول قائد مسلم يدخل شبه الجزيرة الأبييرية عربي يمني وهو القائد طريف بن مالك النخعي كما يذكر ذلك كثير من المؤرخين (3). وإذا كان من المسلم به أن القبائل العربية قد شاركت في حملة طارق بن زياد ذات الأغلبية البربرية (4) فإن المؤكد أن الأغلبية الساحقة من جنود حملة الفتح

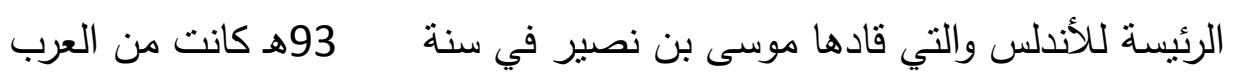
ابن عذاري : البيان المغرب، ج 1 1، تحقيق : ج.س. كولان و : ليفي بروفنسال، ط 3، بيروت، دار الثقافة، 1983م، ص 23-456.

(2) مثال ذلك مملكة الحميريين التي أسسها صالح بن منصور الحميري في بلاد الريف في المغرب

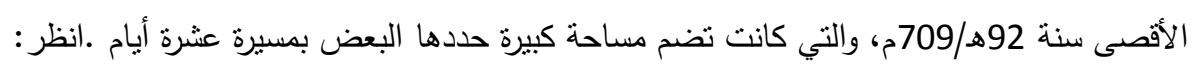

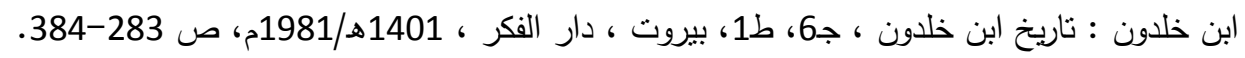

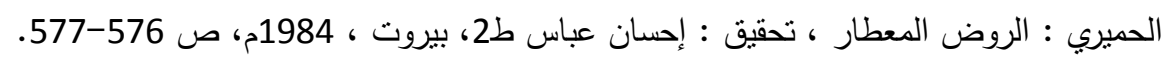

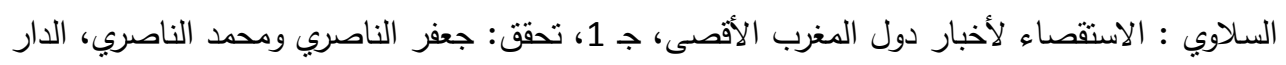

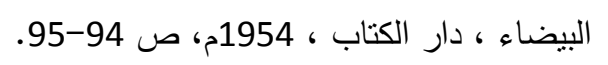

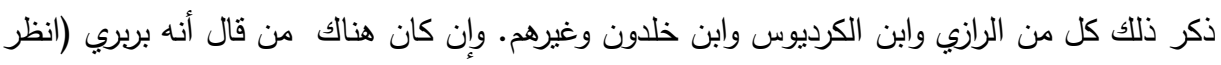

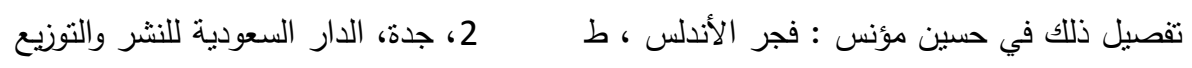

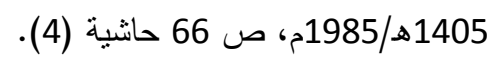

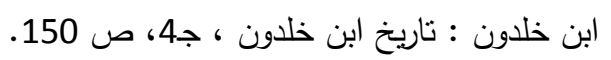

\section{يوليو2009}


اليمانية والثنامية(1). وأنها كانت بمثابة البداية الحقيقية والظاهرة لاستقرار العرب في الأندلس.

\section{مواطن استقرار الأزديين في الأندلس :}

استقر الأزديون - كغيرهم من الفاتحين - في بلاد الأندلس، ويلاحظ المتتبع لكتب التراجم الأندلسية وكتب الجغرافية والبلدان ونحوها وجود الأزديين في معظم أقاليم ومدن الأندلس بداءً من الجزيرة الخضراء(2) . في جنوبي الأندلس ووصولاً إلى أقاصي الثمال والثمال الثرقي لثبه الجزيرة الأيبيرية مروراً بمدن وأقاليم وسط الأندلس.فلا تكاد تلك المصادر تتحدث عن مدينة من المدن الأندلسية إلا ويرد في ثنايا حديثها أعلام بنتسبون إلى الأزد. ومن خلا تتبع تراجم عدد كبير من الأزديين في الأندلس نستطيع القول إن الأغليية منهم قد استقروا في بداية الأمر في جنوبي الأندلس.

وهو بدون شك أمر طبيعي أن تكون مدن جنوبي الأندلس مواطن الاستقرار الأولى للفاتحين القادمين من جنوب شبه الجزيرة الايبيرية. فابن بشكوال يورد في

(1 ) ابن خلدون : المرجع السابق ، ج4، ص 150-151.

(2) الجزيرة الخضراء: وتعرف أيضاً بالخضراء وبجزيرة أم حكيم نسبة إلى جارية طارق بن فئ زياد.

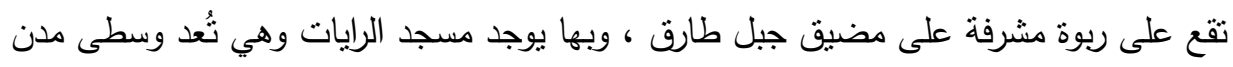

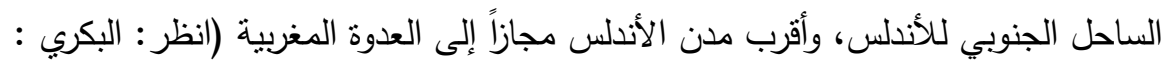

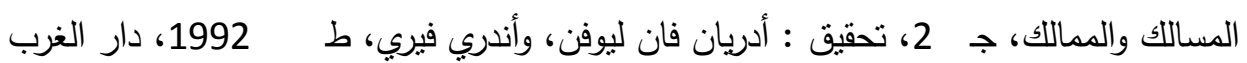

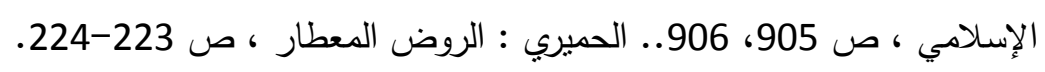
يوليو 2009 العدد الحادى و العثرون 
تراجمه عدداً كبيراً من الأزديين الذين استقروا في الجزيرة الخضراء، ومالقة (1)، والمرية(2)، وغرناطة (3) التي يؤكد ابن الخطيب (4) كثرة وجود الأزديين فيها في معرض حديثه عن سكان هذه المدينة بقوله: " وأنسابهم .. عربية يكثر فيها القرشي والفهري ... والأزدي «. وغيرها من مدن جنوبي الأندلس. كما يثنير إلى وجودهم في مدن الوسط الجنوبي للأندلس في كل من مدينة قرطبة (5)

(1 ) مالقة: مدينة قديمة تقع في جنوب الأندلس ، وهي عاصمة مقاطعة مالقة في إقليم الأندلس - حالياً- وتطل

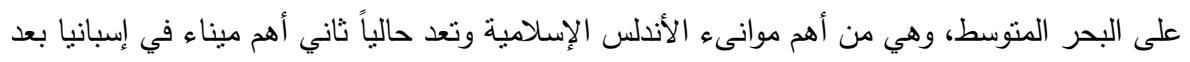

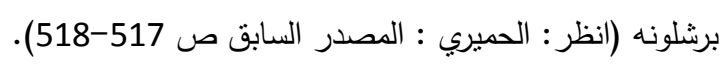

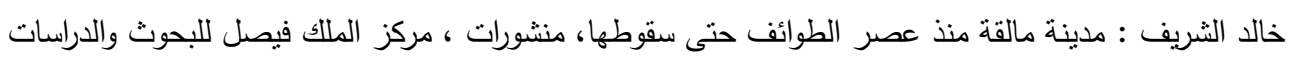

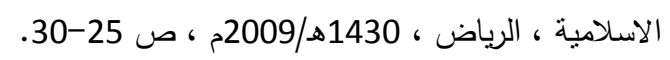
(2) المرية: ميناء أندلسي مشهور على الساحل الجنوبي الثرقي للأندلس، أمر ببنائها الخليفة عبدالرحمن الناصر

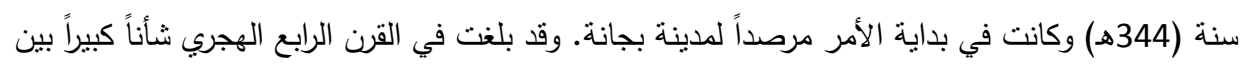

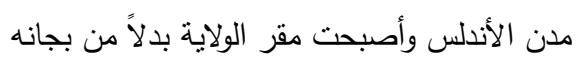

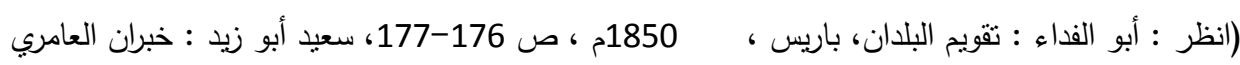

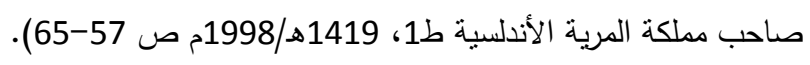

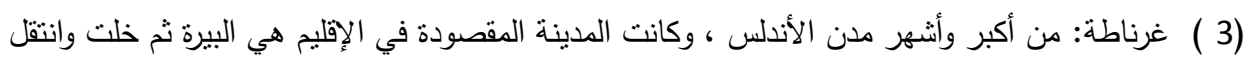

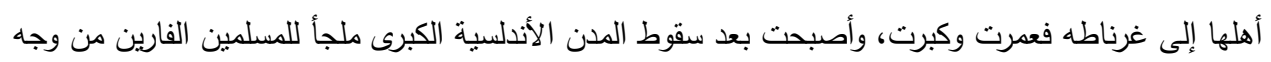

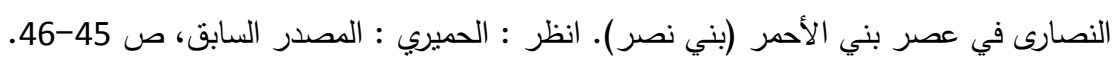

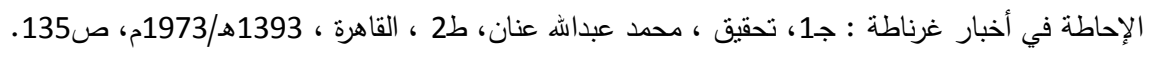

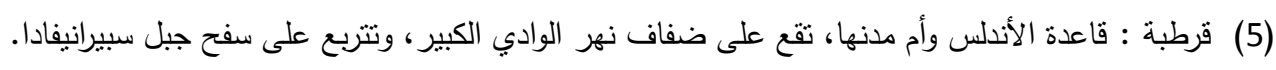

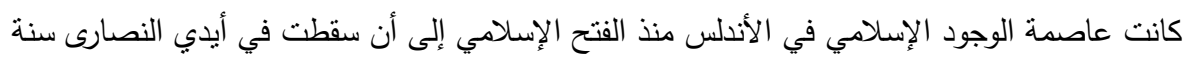

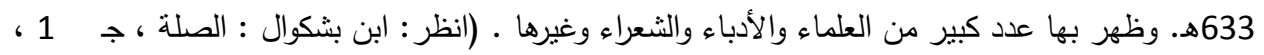

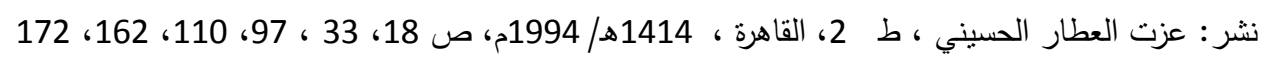
يوليو 12009، 


$$
\text { واستيحة(1) وأثنبيلية(2) وغيرها. }
$$

وإذا ما اتجهنا إلى شرقي الأندلس وجدنا الأزديين بستوطنون مدنها الرئيسة مثل

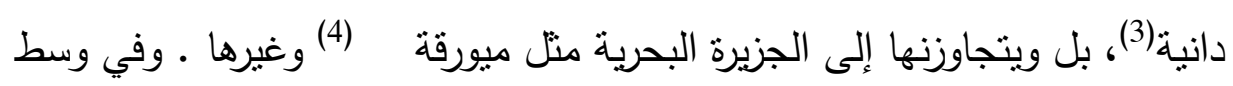
الأندلس استقر الأزديون في مدينة طليطلة (5) عاصمة الثخر الأوسط ، ومنها انساحوا فيما جاورها من مدن وأقاليم وسط الأندلس.

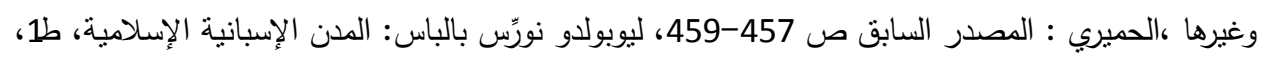

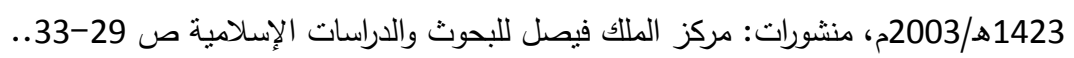

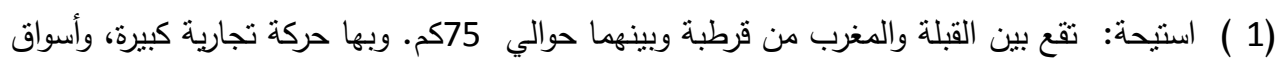

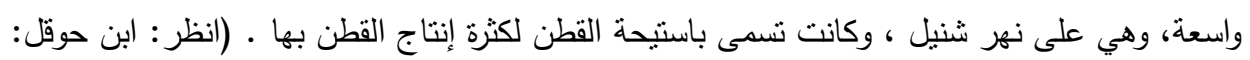

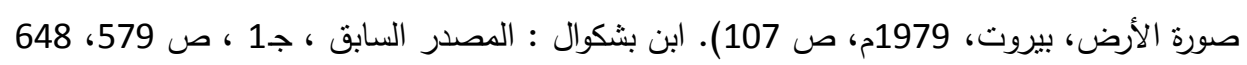
وغيرها .

اثشبيلية : مدينة قديمة تقع إلى الغرب من مدينة قرطبة على نهر الوادي الكبير ولها أقاليم كثيرة تتبعها، كانت تعتبر المقر الرئيس للأسطول البحري في عهد بني أمية، وبها دار لصناعة السفن. (انظر : البكري

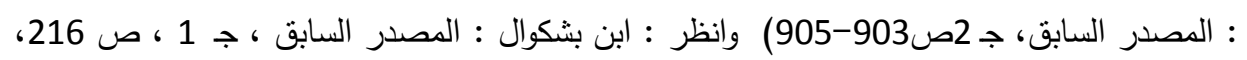
587 وغيرها . دانية : تقع دانية على الساحل الثرقي للأندلس ، وكانت ميناءً بحرياً مهماً في العصر الإسلامي، وبها

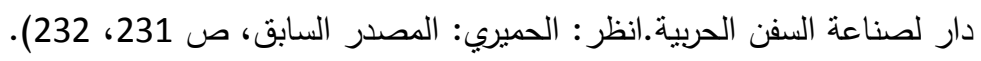

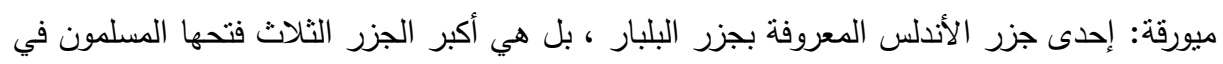

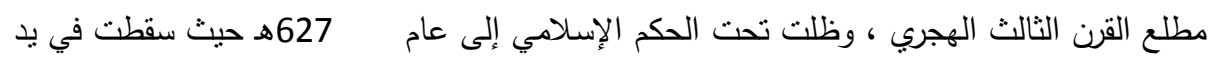

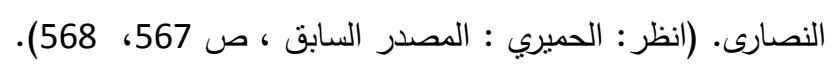

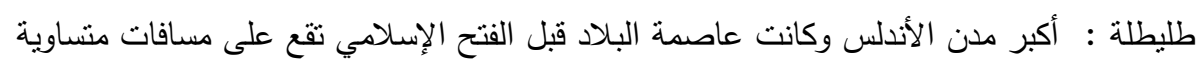

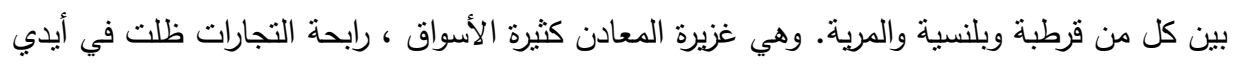

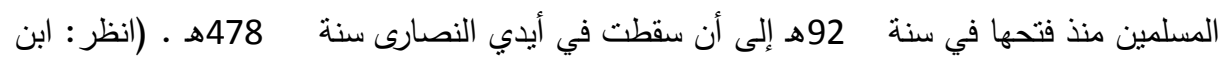

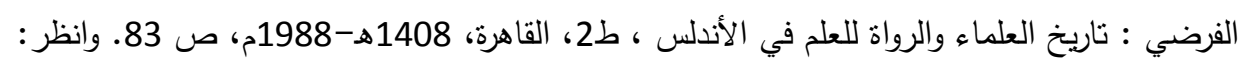
يوليو 2009

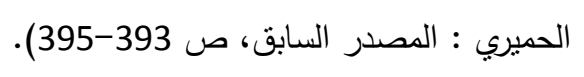


ومن المؤكد أن ثمة مواطن أخرى - غير الأمثلة السابق ذكرها - من مدن وأقاليم الأندلس استقر الأزديون بها ، لم تشر الصادر إليها، وذللك إما لعدم بروز أعلام منهم بدرجة تستوقف المؤلفين، وإما لبروزوهم في مجالات لا تدخل ضمن اهتمام ومجال ما وصل إلينا من كتب التراجم، وإما لكون من ظهر منهم كان في مجالات لا تدخل ضمن مجال هذا البحث ، وشروطه.

\section{الأسر العلمية الأزدية :}

لقد تتوعت العناصر السكانية في بلاد الأندلس بعد القتح الإسلامي ما بين العرب والبربر والأسبان وغيرهم، ونتج عن ذللك التتوع السكاني تلاقح ثقافي متعدد أثمر تراثاً حضارياً أندلسياً متميزاً ، كان لكل عنصر من تلك العناصر إسهامات مشهودة، ومشاركات فاعلة، في ذلك السجل الحضاري الأندلسي العظيم، والمستعرض لذلك الناتج الحضاري الكبير يجد أن للأزبين فيه دور بارز ، وجهد ظاهر ، واسهامات ثرية. ومن خلال تتبعنا لتراجم الأزديين التي أوردها ابن بشكوال في الكتابموضع الدراسة- يتضح الدور المهم الذي اضطلع به الأزديون في رفد الحركة العلمية في الأندلس منذ استقرار المسلمين بها إلى نهاية عصر المؤلف ، وإن كان ذلك الإسهام العلمي لم يكن على وتيرة واحدة وإنما يتضح من خلال نصوص الكتاب أنه يبرز في فنزة ما ، ويخفت ظهوره في أخرى كما أنه يتجلى في مدينة أو إقليم ما، ويخف في جهات أخر تبعاً لعدد من العوامل المؤثرة في الحياة العلمية بصفة عامة ـ فضلاً عن الوجود الأزدي في الإقليم أو المدينة.

يوليو2009

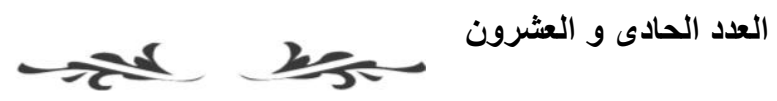


وبالنظر إلى الأندلس بصفة عامة مكاناً وزماناً يظهر العطاء المتواصل

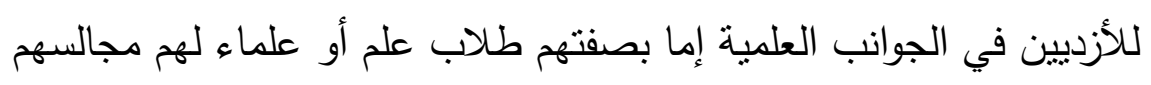
ودروسهم وتلاميذهم أو مصنفين يتتلمذ الطلاب على مؤلفاتهم ، أو وعاظاً وخطباء

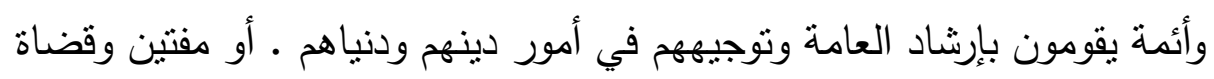
ونحوهم.

وبذلك برز عدد من الأعلام الأزديين في فنون علمية مختلفة بلغوا من العلم غاية بعيدة، وطبقت شهرتهم الأفق ، كما برزت بيوت من الأزد نوارث أبناؤها

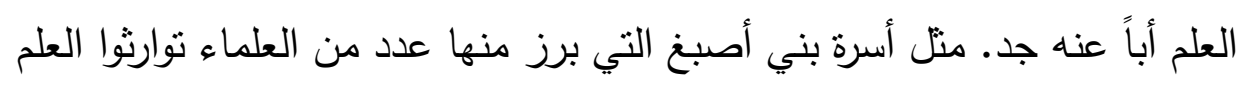
أباً عن جد فكان منهم: محمد بن محمد بن أصبغ الأزدي (ت ب تولى الصلاة بجامع قرطبة. وكان "ارجلاً فاضلاً ، ديناً منواضعاً، مجوداً للقرآن، كثثر العناية بسماع العلم من الثيوخ والاختلاف إليهم ه كما وصفه ابن بثكوال (2). ولا شك أن نوليه أمر الصلاة بجامع قرطبة يدل على علو منزلته في العلم ومكانته بين علماء عصره. ثم أخذ العلم عنه ابنه أبو القاسم أصبغ بن محمد بن أصبغ الأزدي (ت 505هـ)

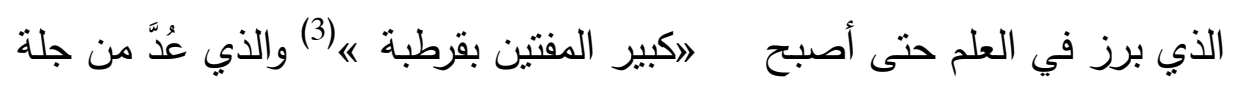

$$
\begin{aligned}
& \text { ابن بشكوال : المصدر السابق ، ج2، ص 524-525. }
\end{aligned}
$$

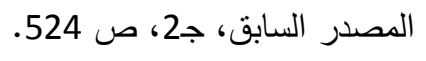

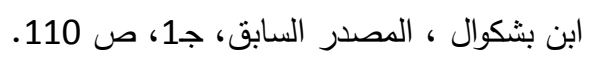

يوليو 2009

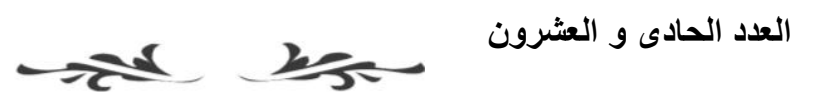


العلماء، وكبار الفقهاء في عصره (1). وقد أهله علمه ومنزلته لتولي عدد من المناصب والمهام حيث كان 》امقداً في الثورى، عارفاً بالثروط وعلاها، ... وتولى

الصلاة بالمسجد الجامع بقرطبة. حدَّث وسمع الناس منه، وناظروا عليه «(2. ثم برز من هذه الأسرة ابنه أبو عبداله محمد بن أصبغ بن محمد الأزدي

(ت536هـ) (3) الذي بلغ من علمه ومكانته أن تولى 》قضضاء الجماعة بقرطبة «(4) وهي مرتبة عالية وكبيرة لا ينالها إلا من كان على قدر كبير من العلم والعدالة والتنكن، فضلاً عن مدى صلته بالحاكم (5).

كما تولى أبو عبداله صلاة الفريضة بجامع قرطبة (6). وكان من رأهل الفضل الكامل والدين والتصاون، والعفاف، والعقل الجيد مع الوقار والسمت الحسن.. كثثر المعروف والخيرات ، مشاركاً بجاهه وماله، كثير البر بالناس «(7). وأضاف ابن بشكوال (8) في صفات أبي عبداله الأزدي أنه اتمة الأعيان بحضرتها - أب قرطبة - .. عديم النظير في وقته ه وكفى بهذا الوصف دليلاً على المنزلة العلمية والمكانة الاجتماعية التي كسبها هذا القاضي الأزدي وأسرته. وكان

$$
\begin{aligned}
& \text { ابن بشكوال : الدصدر السابق ، جـ 1ص110. } \\
& \text { ابن بشكوال : المصدر السابق ، ج1، ص } 110 .
\end{aligned}
$$

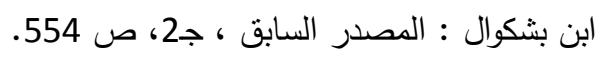

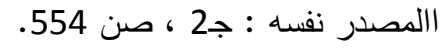

$$
\begin{aligned}
& \text { المصدر نفسه ، ج2، ص } 554 .
\end{aligned}
$$

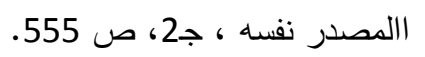

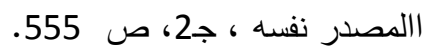

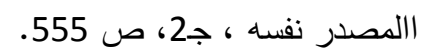

يوليو 2009

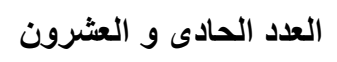


من هذه الأسرة 》أبو بكر عباس بن أصبخ 《 الذي كان من المشايخ الذين جلسوا للتنريس والرواية في قرطبة وكان من تلاميذه الحافظ ابن الفرضي (1).

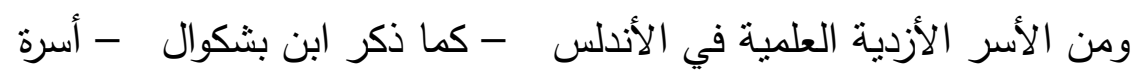

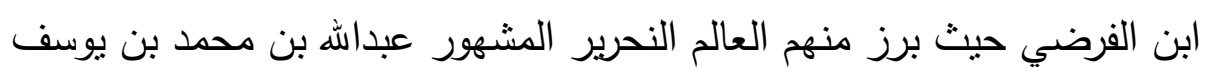

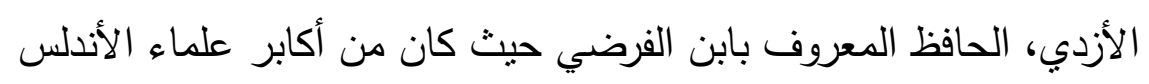

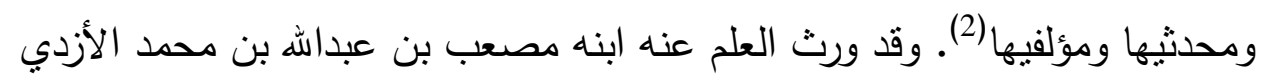

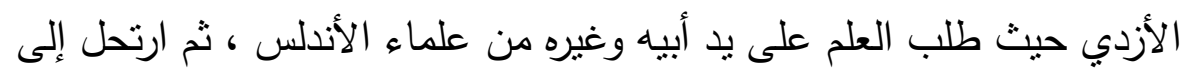

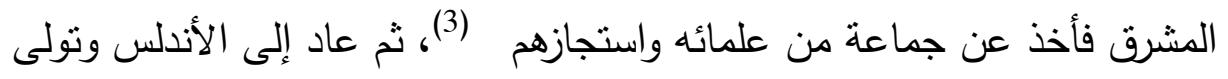
الحكم في الجزيرة الخضراء، وكان 》أديباً ومحدثاً وإخبارياً وشاعراً..، (4).

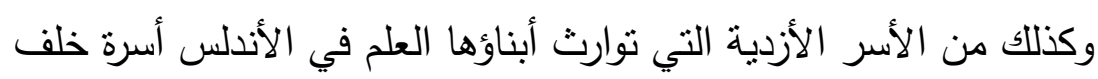

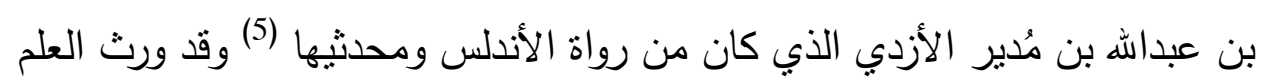

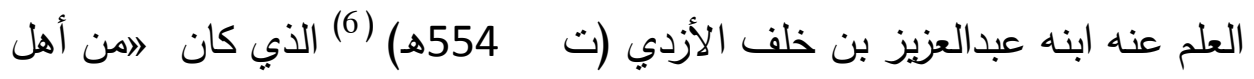
المعرفة والعلم، والذكاء والفهم، أخذ الناس عنده (7).

(1 ) المصدر نفسه ج1، ص 246.

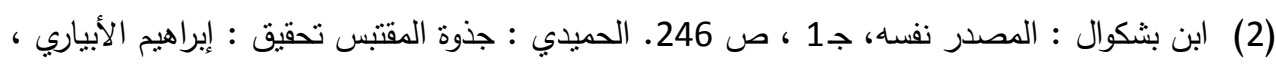
ق1، ط2، بيروت، 1403هـ/1983م، ص 396، 397.

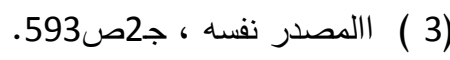

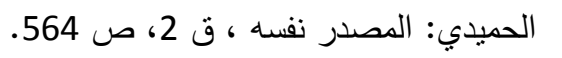
ابن بشكوال ، الدصدر السابق ، ج2، ص الد 355-356.

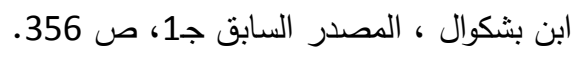

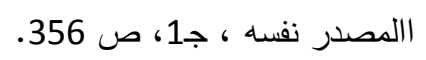

يوليو 2009

$$
\text { العدد الحادى و العشرون }
$$


إلى غير من ذكر من الأسر والبيوتات الأزدية التي أسهم أبناؤها بجهد بارز في الحركة العلمية بالأندلس ، وأصبحت تلك الأسر موضع تقدير واحترام من الخاصة والعامة لاهتمامها بالعلم والدرس، ودورها في رفد الحركة العلمية تدريساً وتأليفاً كما سوف يتضح في ثتايا هذا البحث، بإذن الله تعالى. الرحلة في طلب العلم :

مثلت الرحلة لطلب العلم أهمية قصوى لدى طلاب العلم الأندلسيين بصفة عامة، وعدت الرحلة من أهم وأشهر وسائل تلقي العلم، وتبادل صنوف المعرفة، وكانت منزلة العالم تزيد وترتفع بارتحاله لطلب العلم، ويزداد عدد المتحلقين في درسه ، بل ويدنو من الحاكم ، وتكون الرحلة طريقاً لتسنمه المناصب العالية في البلاد، وتولية الخطط الرئيسة في الدولة عامة وبلدته خاصة (1).ولذا حرص معظم طلاب العلم من الأندلسيين على الارتحال من الأندلس إلى خارجها - وخاصة إلى المشرق الإسلامي - لطلب العلم ، والأخذ عن علمائه المشهورين في فنون العلوم المختلفة، وكانوا يحرصون على النهل من علمهم، والحصول على إجازاتهم العلمية. ومن ثمَّ بعودون إلى الأندلس محملين بما وعته صدورهم من تللك العلوم والمعارف. وما حوته مدوناتهم، أو حملته وسائل نقلهم من ألوان التصانيف، والتآليف من علماء المشرق على امتداده حيثما وصلت بهؤلاء الأندلسيين الرحلة (2).

عواطف نواب: الرحلات المغربية والأندلسية، الرياض، مكتبة الملك فهد الوطنية، 1417هـ/1996م، ص 91-

عواطف محمد نواب: المرجع السابق ، ص 76-78.

يوليو 2009 
وعلى هذا سار طلاب العلم من الأزديين في الأندلس فحرص الكثير منهم على

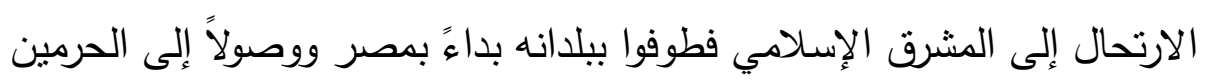
الثريفين في مكة والدينة ومنهم من امتدت رحلته إلى العراق وما وراءها، وبلاد

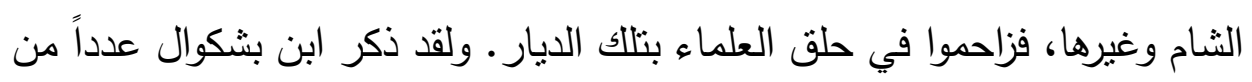
الأزديين الراحلين إلى المشرق في طلب العلم ومنهم :

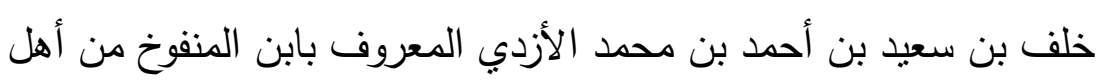

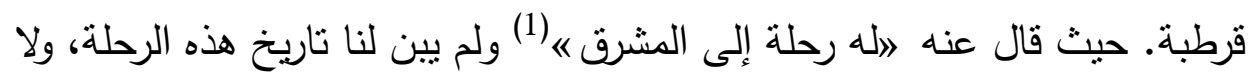

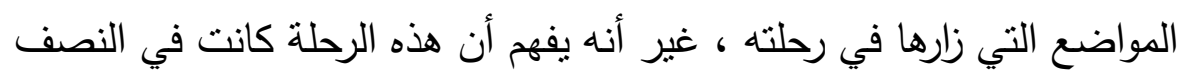

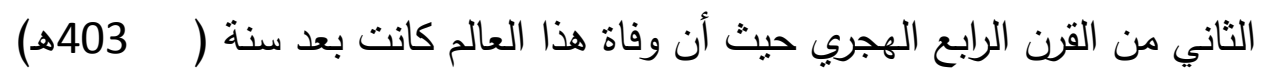

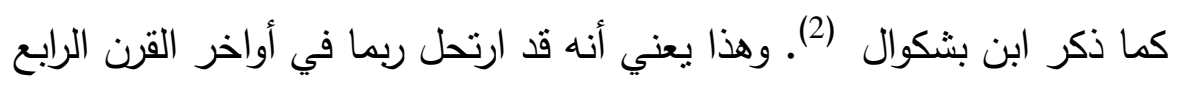

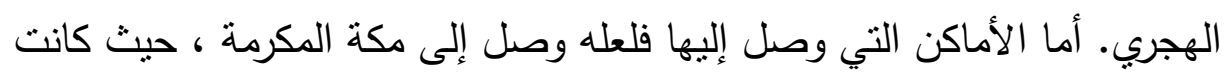

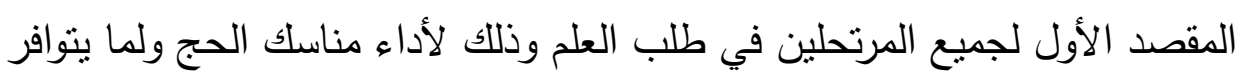

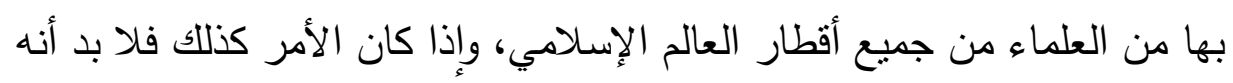
قد مر بمصر ولعله أخذ عن علمائها وكذلك علماء القيروان وفاس وغيرها من

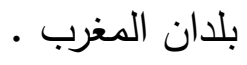
ويشير ابن بشكوال في ترجمته لهذا العلم أنه 》كان مشاوراً في أشبيلة)|(3).

ابن بشكوال ، المصدر السابق، ج1، 162.

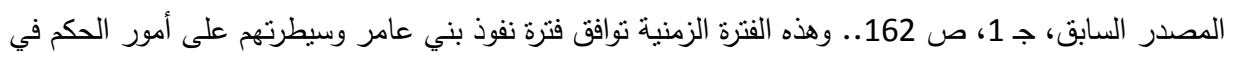

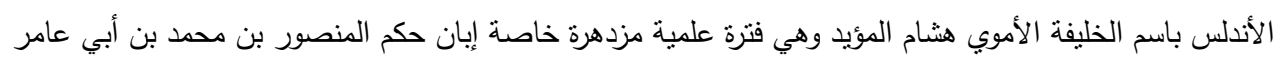

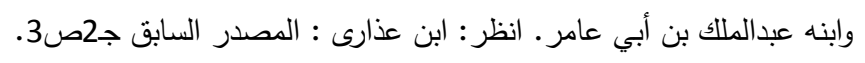

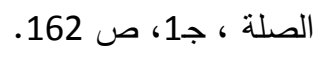

يوليو 2009

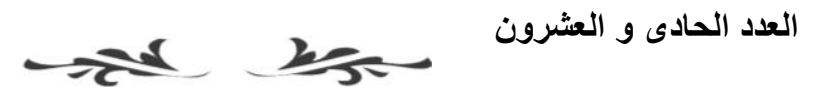


ولا شك أنه لن يبلغ ذلك إلا بما حازه من علم ومعرفة أهلته لأن يكون من

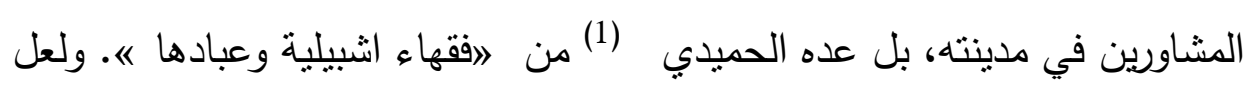
رحلته إلى المشرق كانت العامل الأبرز في تحقق ذلك له (2).

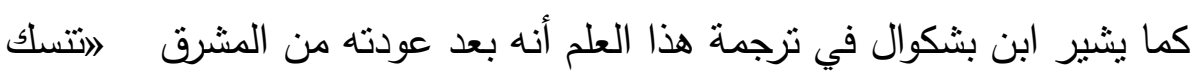

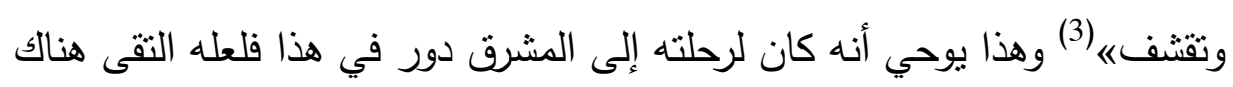

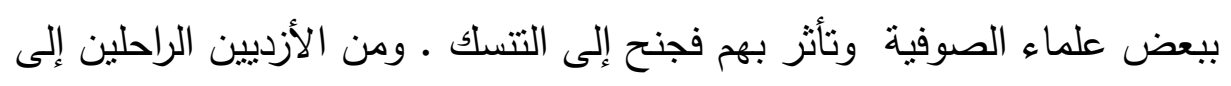

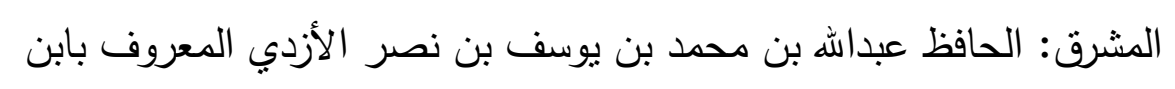

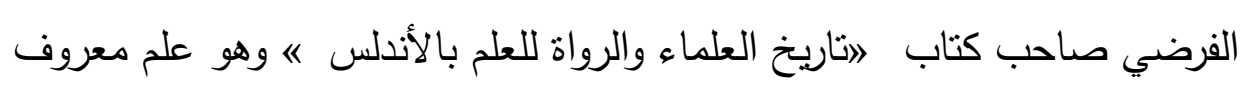
رحل إلى المشرق سنة 382هـ فدخل القيروان (4) وأخذ عن علمائها ومنهم أبو الاني

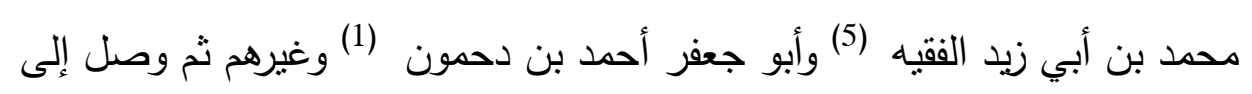

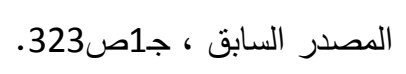

(2) مما يدل على غزارة علمه ومكانته أن من طلابه ابن عبدالبر العلم المشهور الذي أخذ عنه وأثنى عليه

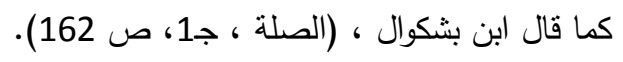

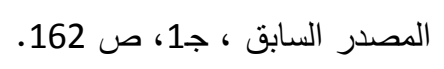

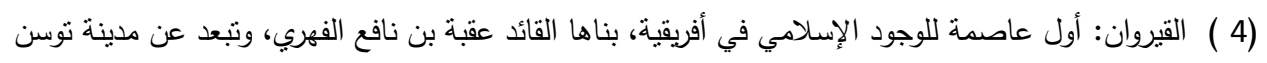

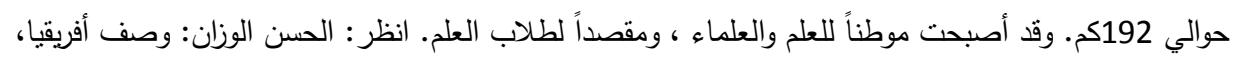

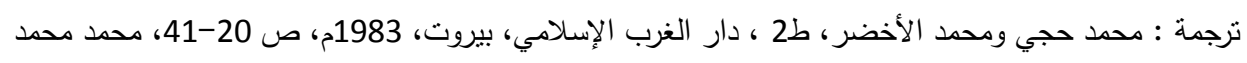

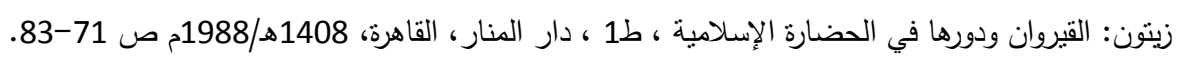

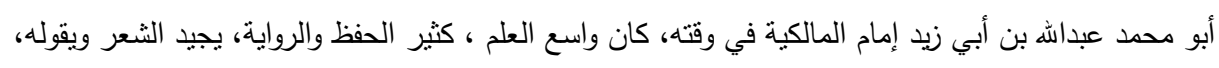

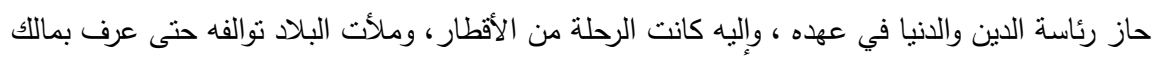

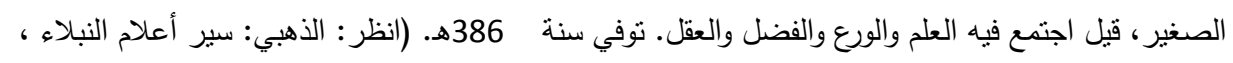

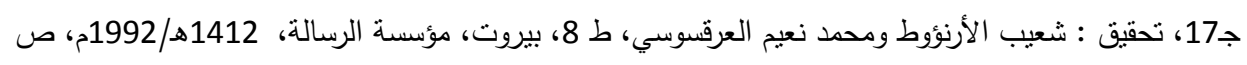

\section{يوليو2009}


مصر وأخذ عن أبرز علمائها ومنهم: أبو بكر أحمد بن محمد بن اسماعيل

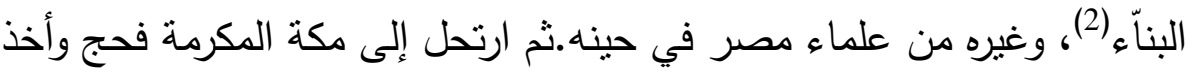

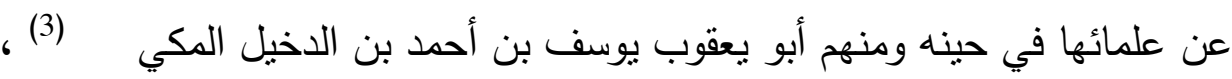

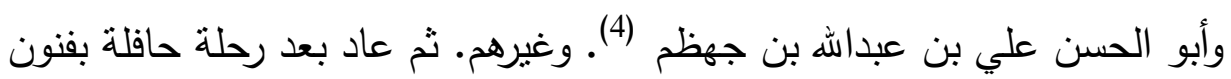

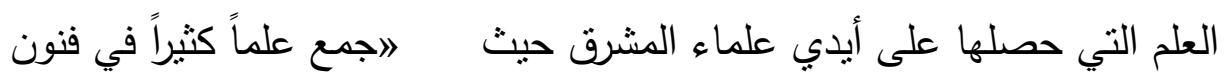

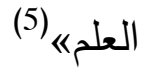

وبدأ رحلة جديدة في التأليف والتدريس والإقراء فاق بها علماء عصره. وكان

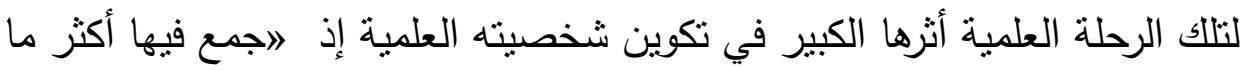

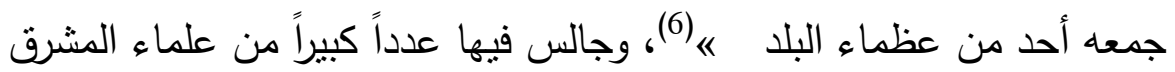
لم أجد له ترجمة فيما اطلعت عليه.

أبو بكر أحمد بن محمد بن إسماعيل البناء يعرف بابن المهندس من علماء مصر المشهورين. رحل إلى الى

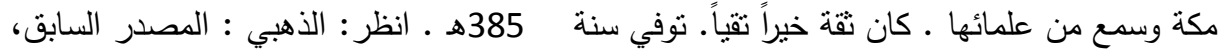

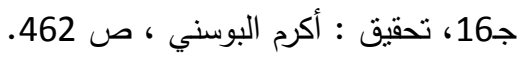

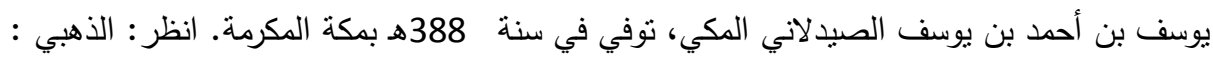

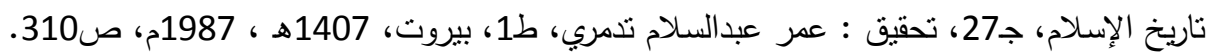

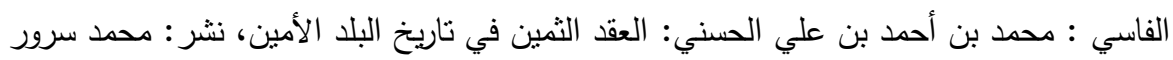

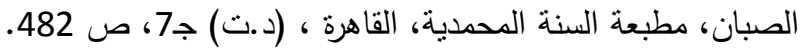

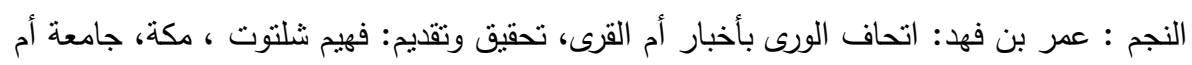

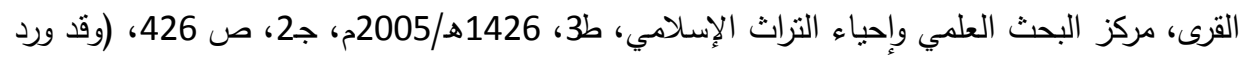

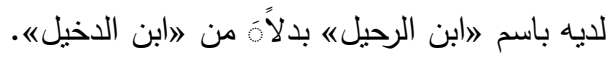

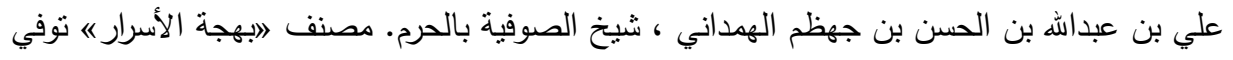

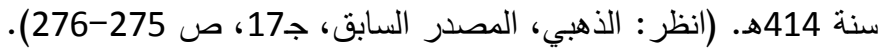

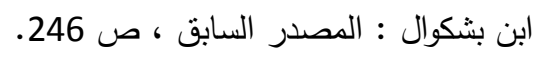

$$
\begin{aligned}
& \text { ابن بشكوال : المصدر السابق ، ص ص } 246 .
\end{aligned}
$$

يوليو 2009

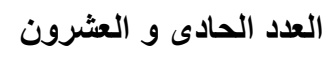


الإسلامي الكبار من المحدثين والفقهاء والرواة وغيرهم لذا كان ابن الفرضي لافقيهاً عالماً في جميع فنون العلم في الحديث وعلم الرجال ... « (1) وأصبح من كبار مؤلفي الأندلس وعلمائها البارزين حتى قيل الم ير مثله بقرطبة من سعة الرواية وحفظ الحديث، ومعرفة الرجال، والافتتان في العلوم إلى الأدب البارع والفصاحة المطبوعةه (2)، وكان - رحمه الله من قضاتها المشهورين، حيث تولى القضاء في بلسنية في دولة محمد المهدي المرواني ( 399-400هـ)3. وكان ذلك بعد رجوعه من رحلته إلى المشرق الإسلامي.

وممن رحل إلى المشرق من الأزديين عبداله بن سعيد الأزدي من اهل استجة حيث طلب العلم هناك على أيدي العلماء الذين التقى بهم في رحلته هذه ومنهم عطية بن سعيد (4) وغيره.

ثم عاد إلى الأندلس فحدث بها وجلس للتدربس والتعليم (5) ـ ولم يبين المؤلف رحلة رحلة هذا الأزدي متى كانت وإلى أين انته ، غير أن الذي يمكن القول به أن

(3) المصدر نفسه ، ص 248 المصد ، 248.

(4) المصدر نفسه ، ص 248. وانظر ابن حزم : رسائل ابن حزم الأندلسي، ج 2 ، تحقيق إحسان عباس ، ط 13،

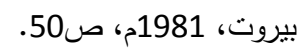

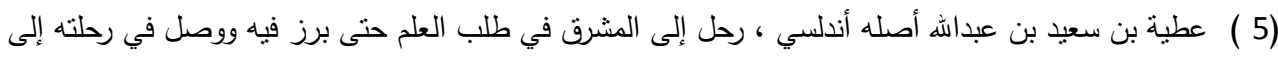

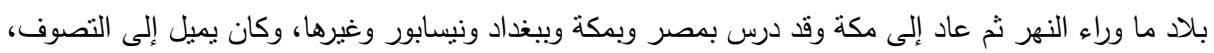

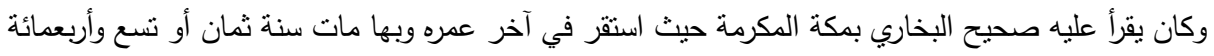

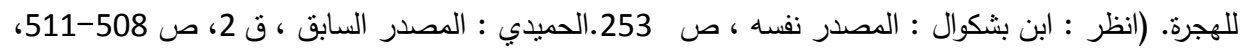

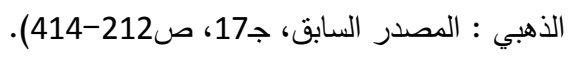

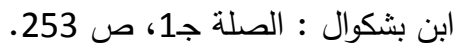

يوليو2009

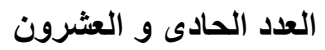


هذه الرحلة كانت في نهاية القرن الرابع الهجري أو في مطلع الخامس الهجري حيث

ذكر أنه درس على عطية بن سعيد المتوفى في مطلع القرن الخامس الهجري (1). وكما كانت رحلات أغلب الأندلسيين تتجه إلى الحرمين الثريفين فلعل رحلة أبي محمد قد وصلت إلى مكة المكرمة في أدنى الأوجه. يستفاد هذا من تتلمذه على عطية بن سعيد الذي استقر في آخر عمره بمكة ودرس بها (2) ـ وبعد عودته إلى الأندلس جلس للتعليم والدرس في مدينة أستتجة فأخذ عنه طلاب العلم وكان من أبرز تلاميذه القاضي يونس بن عبداله (3). ومن أنشهر من رحل من أزد الأندلس وامتدت رحلته حتى بلغ أقاصي العراق محمد بن أبي نصر فتوح بن عبداله الأزدي الحميدي. وكان - رحمه اللهمن أهل جزيرة ميورقة فيما أصله من ربض الرصافة في قرطبة كان قد طلب العلم في الأندلس على يد كبار علمائها منل أبي محمد علي بن أحمد بن حزم الظاهري(4)، ولازمه فترة طويلة وأكثر النقل عنه، وكذلك أخذ عن أبي العباس

$$
\text { الذهبي: المصدر السابق ،ج 17صدئ. المصدر. }
$$

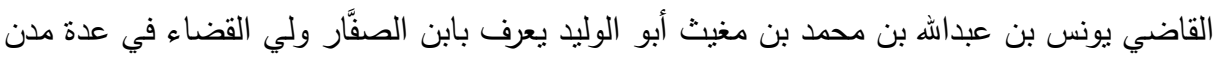

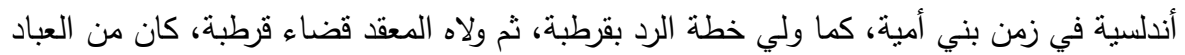
الزاهدين ميالاً إلى التصوف في العبادة، ألف العديد من الكتب في التفسير والاعتقاد، والرقائق والأخبار

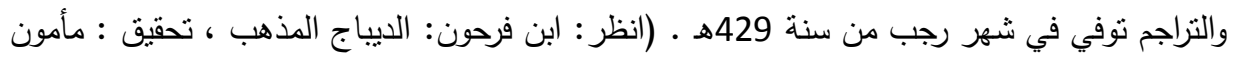

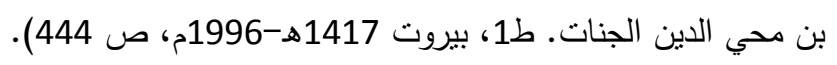

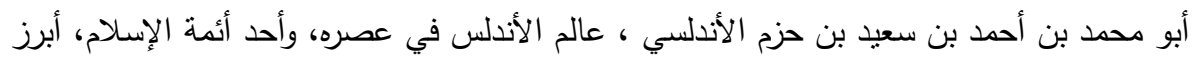

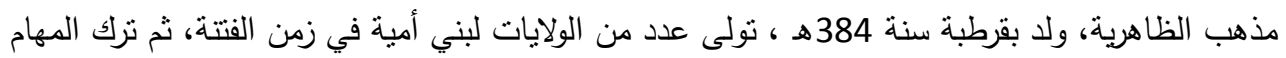

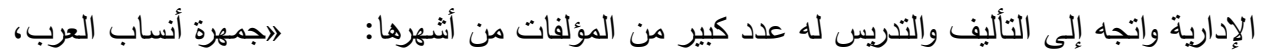
يوليو 2009

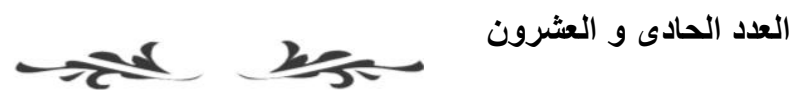


العذري(1)، وعن أبي عمر بن عبدالبر (2) ـ ورغم غزارة ما أخذه عن هؤلاء العلماء الكبار في الأندلس فإنه لم يكتف بذلك بل عقد العزم على الرحلة إلى المشرق لاستكمال طلب العلم فغادر الأندلس في سنة 448هـ متجهاً إلى مكة المكرمة لأداء فريضة الحج حيث حقق الله له ذلك، وبمكة جالس العلماء وطلاب العلم وأخذ

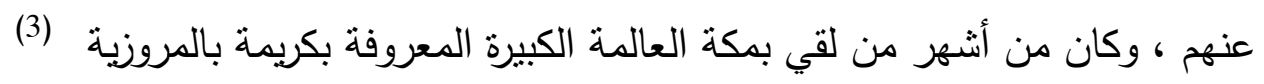
حيث طلب العلم على يديها وحدث عنها (4). وكان في طريقه إلى مكة قد طلب العلم على علماء مصر وأفريقية كثيراً (5)، وبعد أن فرغ من أداء الحج واصل رحلته

والرسائل ه وغيرها قيل أنها فاقت 400 مجلد . (انظر نرجمة مطولة له في مقدمة كتاب جمهرة أنساب العرب وضعها لجنة من العلماء بإنشراف محمد علي بيضون).

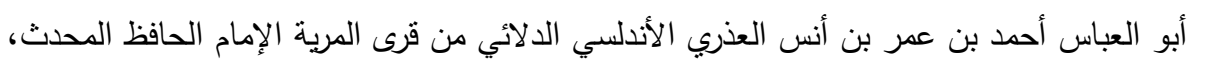

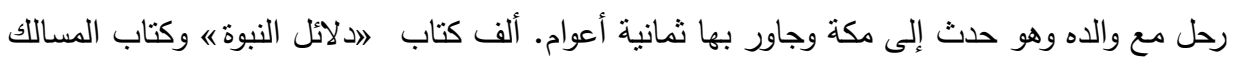

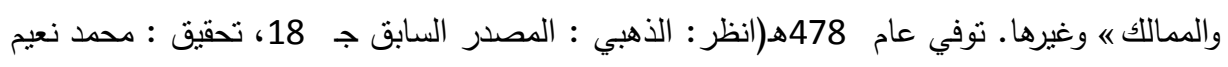

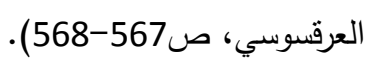

أبو عمر يوسف بن عبداله بن محمد بن عبدالبر النمري الأندلس الإمام المجتهـ الحافظ محدث عالم

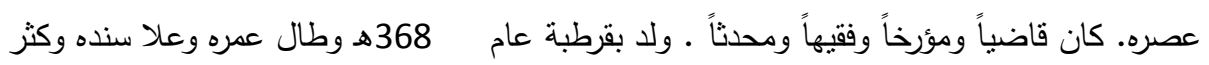

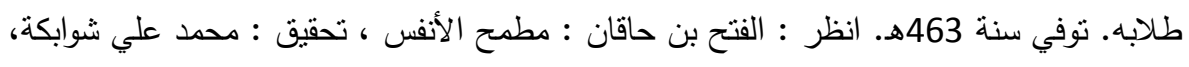

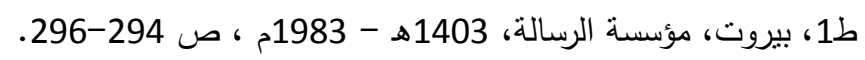

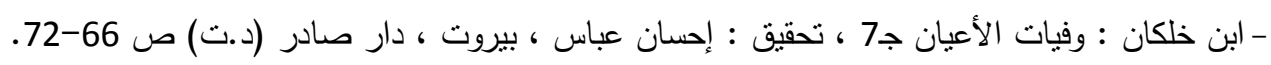

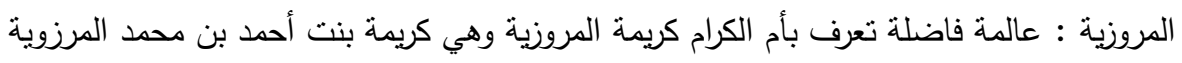
المتوفاة سنة 463هـ ـ كانت عالمة فاضلة مشيدة، ذات فهم ومعرفة ـ انظر : الذهبي الذبي : سير أعلام

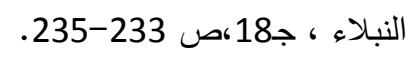

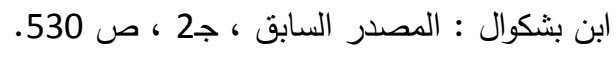

يوليو2009

$$
\begin{aligned}
& \text { المصدر نفسه ، ج2، ص الح } 530 . \\
& \text { العدد الحادى و العشرون }
\end{aligned}
$$


إلى بلاد الثام ثم إلى العراق حيث استوطن ببغداد واستقر بها ، وبها نوفي في عام

(1) 488

وقد لقي الحميدي في رحلته هذه عدداً كبيراً من المشائخ والعلماء في افريقية ومصر والثام ومكة المكرمة، حتى إذا وصل إلى العراق قبلة العلم في حينها واستقر بها طاف مجالس علمائها فأخذ عنهم العلم وطارحهم مسائلة وثثى الركب في مجالس كبار علمائها منل أبي بكر الخطيب (2)، وأي نصر بن ماكولا (3)، وغيرهم من علماء بغداد الكبار الذين شهدوا بدورهم للحميدي بالعلم والفهم والفضل والتيقظ (4). وفي بغداد شغل الحميدي إلى جانب التدريس بالكتابة التأليف كما سيأني بيانه. وأختم الحديث عن رحلات الأزديين إلى المشرف لطلب العلم بالحديث عن رحلة علم آخر من أزديي الأندلس ألا وهو طاهر بن هشام بن طاهر الأزدي الذي رحل إلى المشرق حاجاً وطالباً للعلم. بعد أن درس في الأندلس على أيدي علمائها

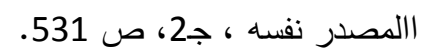

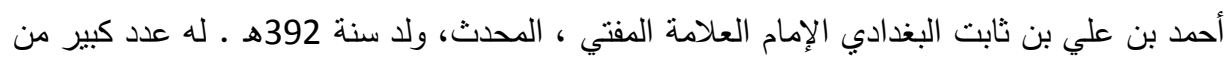

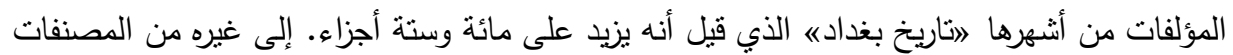

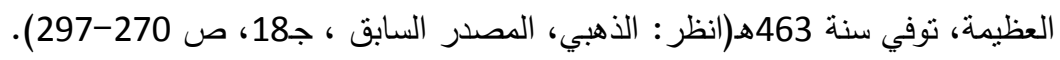

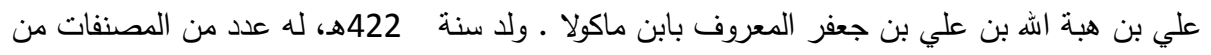

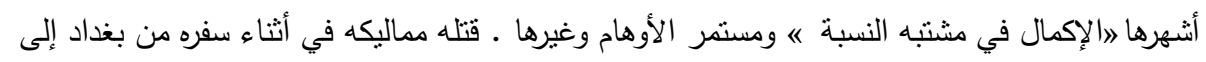

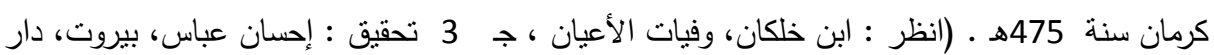

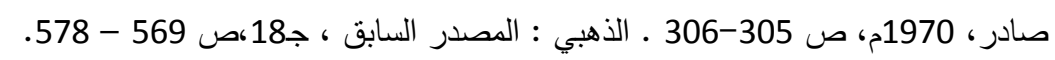

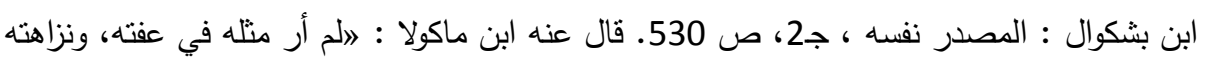

يوليو 2009

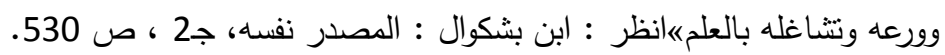

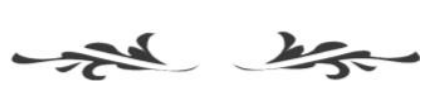

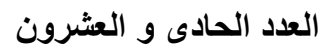


الكبار من أمثال الفقيه المحدث القاضي المهلب بن أبي صفرة (1)غيره(2).وفي

طريقه إلى المشرق أخذ عن عالم القيروان الشهير أبي عمران الفاسي (3)

وفي مكة أخذ العلم عن أشهر علمائها ومنهم شيخ الحرم أبي ذر الهروي (4). وحين عاد طاهر الأزدي إلى الأندلس كان قد حصل نصبياً وافر من العلم أهله

لتولي الفتيا في المرية (5).

(1) أبو القاسم المهلب بن أحمد بن أسيد بن أبي صفرة التميمي من أهل العلم الراسخين في الفقه والحديث التباء

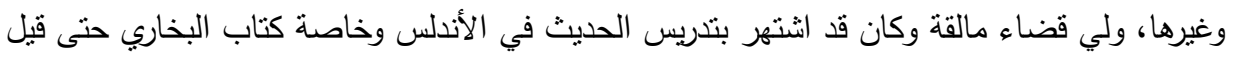

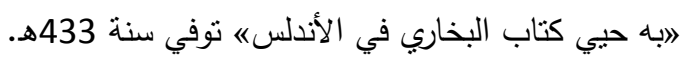

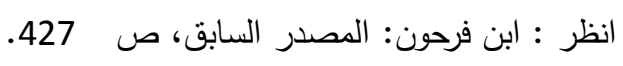

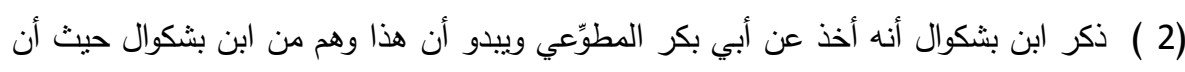

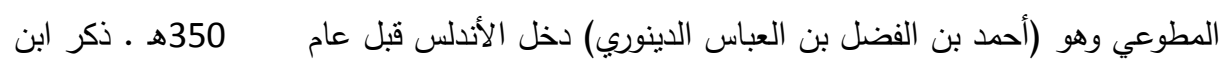

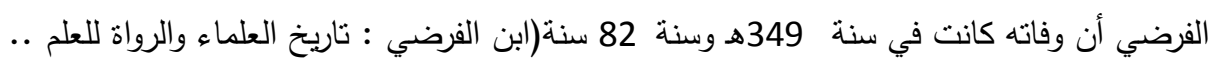

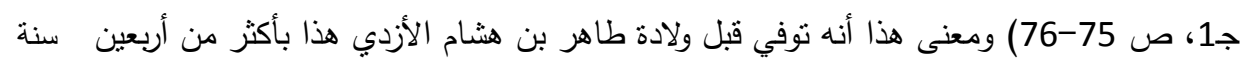

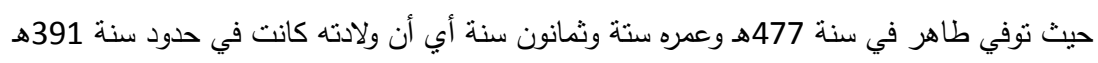

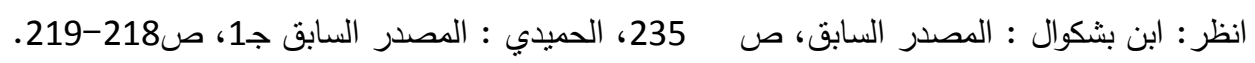

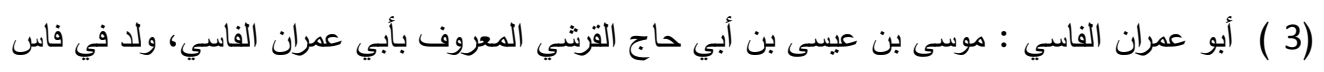

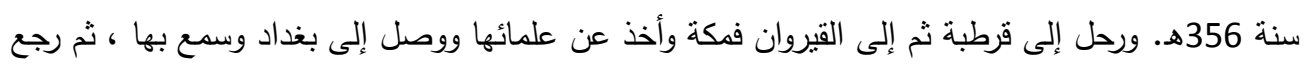

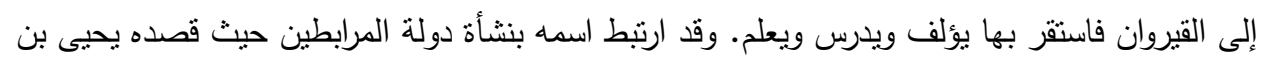

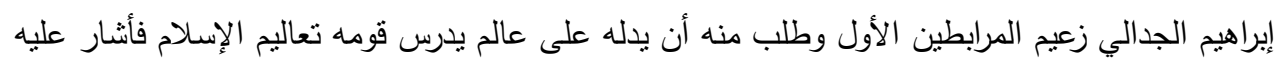

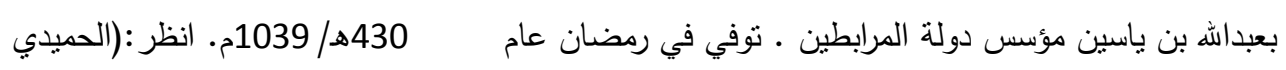

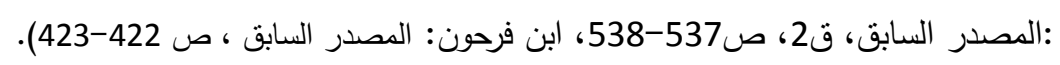

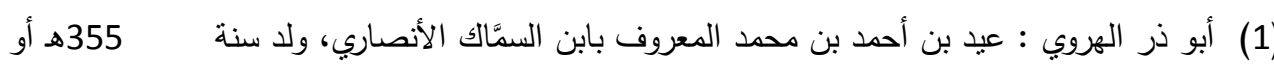

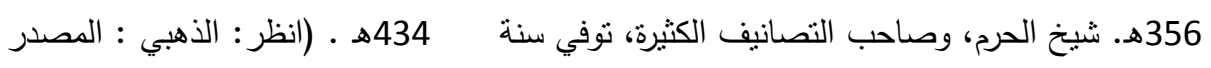

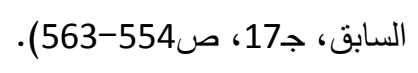

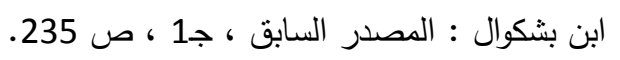

يوليو2009 
ومن خلال ما سبق يتبين لنا أنه كان للأزديين حضور واضح في الرحلة العلمية،

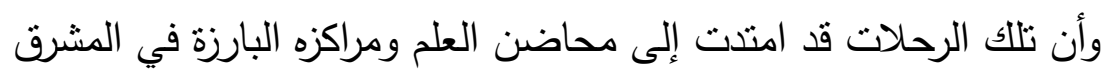

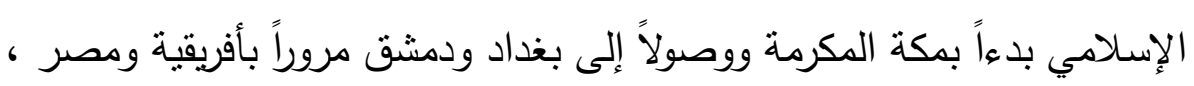
تللك المراكز المشعة بالعلم المليئة بحلق العلماء ومجالسهم ، وحظى الأزديون

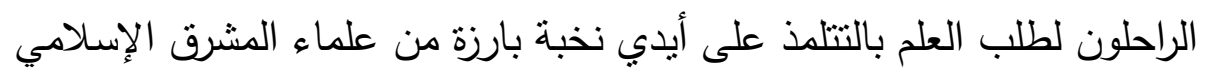

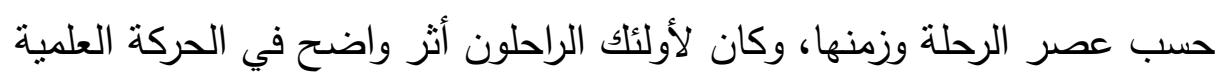

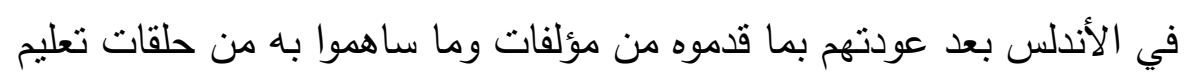
وتدريس ، وما اضطلعوا به من مهام القضاء والفتيا وغيرها مما سيأني بيانه.

\section{-دور الأزديين في التصنيف 》التأليف《 :}

من خلال استعراض تراجم الأزديين لدى ابن بشكوال يتضح أن عدداً منهم

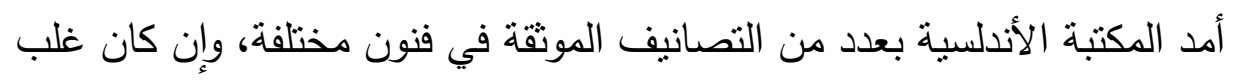

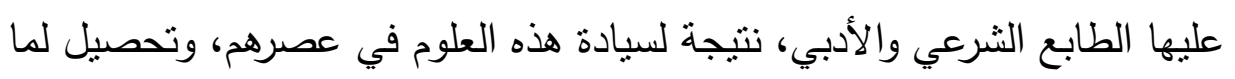
تلقوه على أيدي العلماء والأدباء الذين تتلمذوا على أيديهم في الأندلس أو في المشرق الإسلامي ـ وكان لبعض نلك المؤلفات أثرها ودورها الواضح في رفد

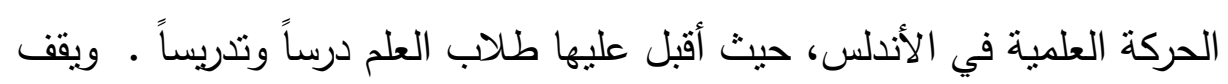


على رأس قائمة المؤلفين الأزديين المترجم لهم في الصلة العلم الثهير عبداله بن محمد الأزدي المعروف بابن الفرضي الذي أمد طلاب العلم في الأندلس وغيرها بعدد من المؤلفات، أبرزها مؤلفه اتاريخ علماء الأندلس «"(1) والذي نشر بعنوان

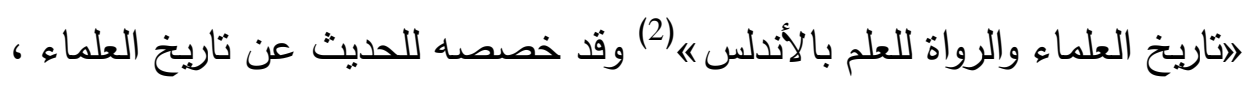

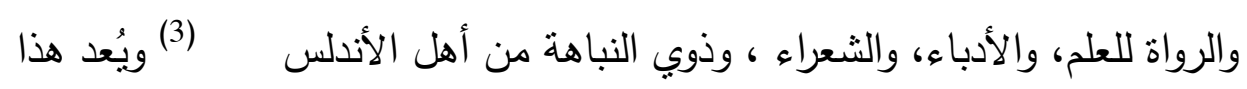
المؤلف من أقدم كتب التراجم في الأندلس ومن أوثقها حيث وصف مؤلفه بأنه : "حافظاً ، متقناً عالماً، ذا حظ من الأدب وافر "(4). ووصفه ابن عبد البر (5) بأنه : ״فقيهاً عالماً في جميع فنون العلم... «. بل اعتبره البعض أقدم معجم لتراجم الرجال في الأندلس (6) - (2) - (2)

وقد اعتمد كثثر ممن ألف في التراجم الأندلسيين بعد ابن الفرضي على هذا

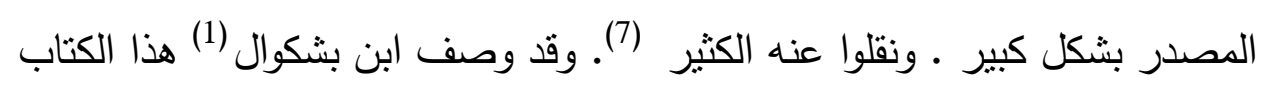

(1 ) ابن بشكوال : المصدر السابق ، ج1 ، ص 246.

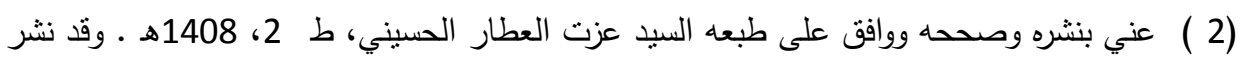

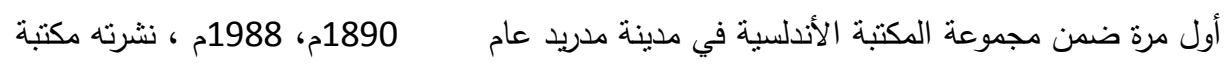
الخانجي بالقاهرة.

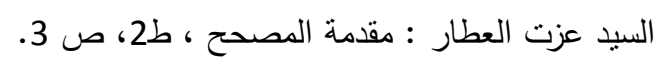

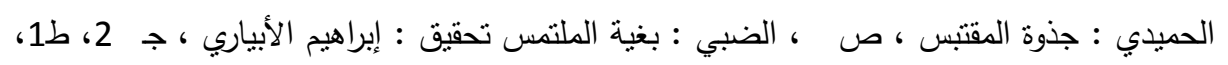

$$
\begin{aligned}
& \text { بيروت، 1410هـ/1989م، ص 433. } 43 \\
& \text { انظر : الصلة ج1 ، ص } 246 .
\end{aligned}
$$

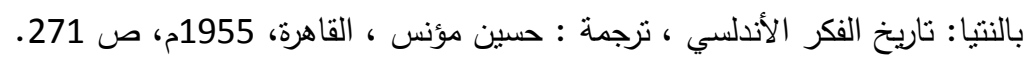

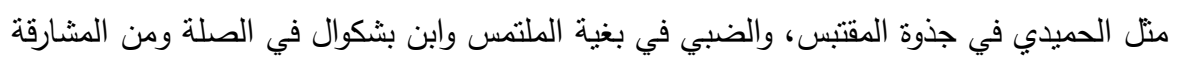
الذهبي في سير أعلام النبلاء وغيرهم. (انظر : حمد السحيباني: مصادر الحافظ ابن الفئ الفرضي في في كتابه يوليو 2009 
الكتاب بقوله: 》بلغ فيه النهاية والغاية من الحفل والاتقان 《 ـ ووصلة بكتابه الصلة.

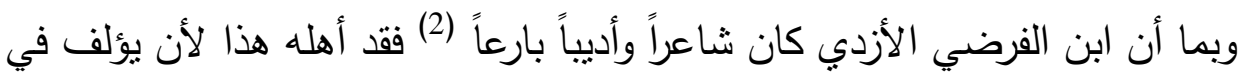
هذا الفن "كتاباً حفيلاً في أخبار شعراء الأندلس " خصصده لتنراجم من غلب عليه الثعر والأدب في الأندلس (3).

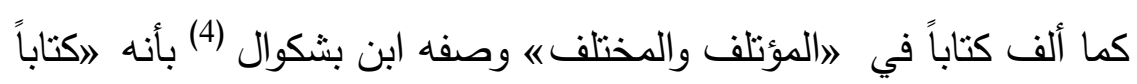
حسناً). ووصفه ابن حزم (5) بقوله " لا أعلم منلكه في فنه البتة هـ وله مؤلف آخر

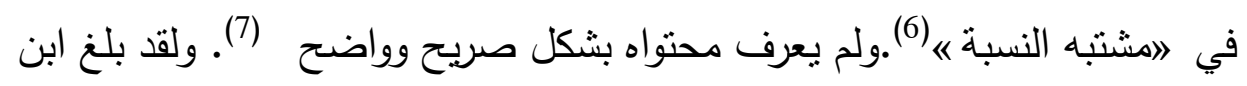
الفرضي الأزدي مكانة رفيعة في العلم بين طلاب الأندلس، وأصبح من كبار

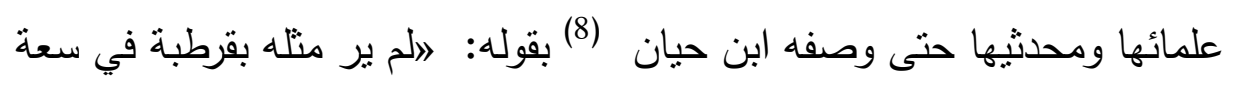

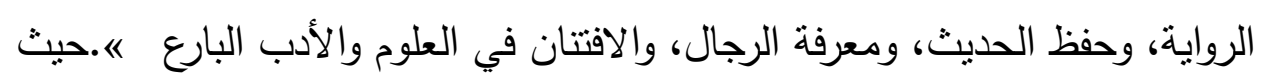

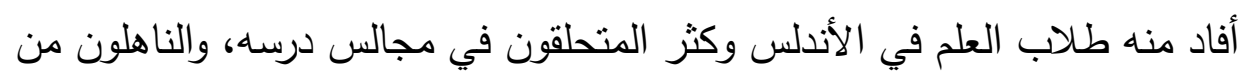
مؤلفاته.

تاريخ العلماء والرواة ، مجلة جامعة أم القرى لعلوم الثريعة واللغة العربية وآدابها ، المجلد 120 12 12 العدد

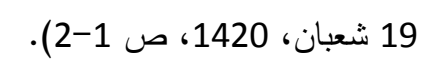

$$
\begin{aligned}
& \text { ابن بشكوال : المصدر نفسه ، ج1،ص إص } 2462
\end{aligned}
$$

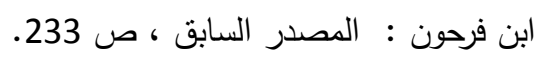

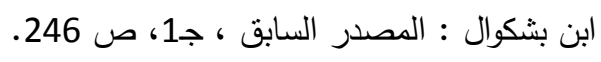

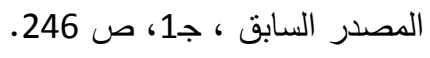

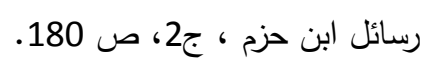

ابن بشكوال : المصدر السابق ، ج1 ، ، صـ 246 ـ ـ وانظر : الذهبي : سير أعلام النبلاء ، ج178، ص

انظر : السحيباني ، المرجع السابق ، ص 4.

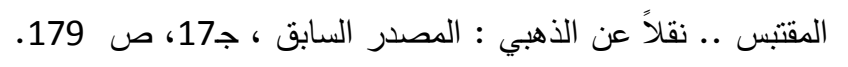

يوليو 2009 العدد الحادى و العشرون 
وممن اشتخل بالتأليف في الأندلس من الأزديين خلف بن عبداله بن سعيد بن مُدير الأزدي المنوفى سنة 495هـ. حيث قال عنه ابن بشكوال (1): لاكان ثقة فميا رواه، ضابطاً لما كتبه، حسن الخط، كثثر الجمع والتقييد وكتب علماً كثيراً بخطه ورواهه • ولم يبين ابن بشكوال تحديداً مسميات تلاك التآليف والكتب التي ذكر أن ابن مدير قد كتبها. غير أنه أكد أنتاء ترجمته لعبيد بن علي الأزدي أنه استفاد تلك الترجمة من ابن مُدير فقال: „ذكره ابن مُدير ... « (2) ـ وأثتاء ترجمته لطاهر بن هشام قال: 》وفال ابن مددير توفي سنة... « (3). ومن خلال تتبع العلماء الذين تتلمذ على أيديهم خلف به مُدير (4) يتضح أن الغالب عليهم العلوم الثرعية مما يوحي أن كتبه كانت في هذا المجال تحديداً، يؤيد ذلك أنه كان يقرىء الناس بقرطبة حينما سكنها (5) وكان خطيباً بالمسجد

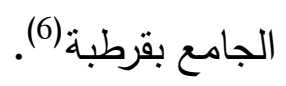
ويأتي الحميدي : محمد بن أبي نصر بن فتوح الأزدي المنوفى عام (488هـ) ضمن أبرز المؤلفين من الأزديين الذين ترجم لهم ابن بشكوال في ترجمة

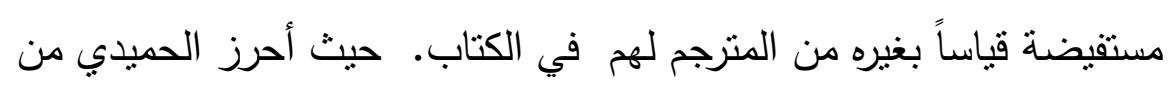

$$
\begin{aligned}
& \text { (4) المصدر نفسه ، جـ 1، ص } 170 . \\
& \text { (5) ابن بثكوال: المصدر السابق ، ج2، ص صل } 421 . \\
& \text { المصدر نفسه ج1، ص } 235 . \\
& \text { وكان من أبرزهم أبو عمر بن عبدالبر ، وأبو العباس العذري، وأبو الوليد الباجي.. وغيرهم. }
\end{aligned}
$$

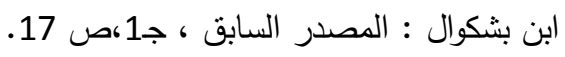

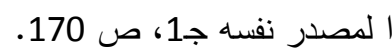

$$
\begin{aligned}
& \text { يوليو } 2009
\end{aligned}
$$

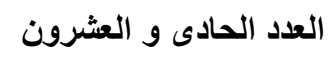


خلال رحلاته العلمية - المشار إليها سابقاً - علماً جماً ترجمة في مؤلفات علمية جليلة أصبحت منهلاً لطلاب العلم. ومن أشهر مؤلفاته التي ذكرها ابن بثكوال

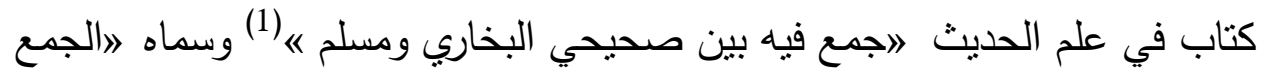

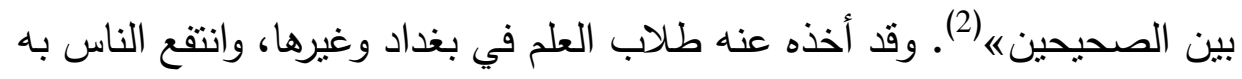
كثبراً (3).

وقد بلغ من ولعه بالعلم والدرس وتعلقه بنسخ ما يقع في يديه من الكتب أن

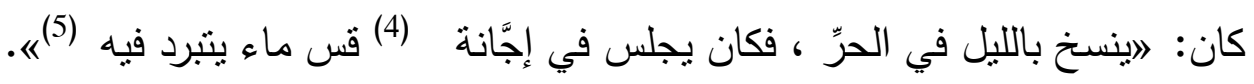

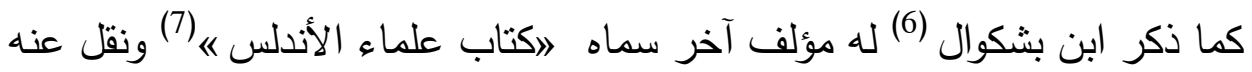
عنه ابن بشكوال الكثير من تراجمه، وبما أن الحميدي كان من المتضعلين في عدد

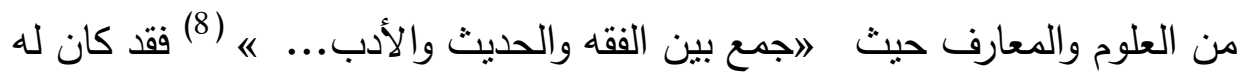

(4) المصدر نفسه ، ج2،ص 530.

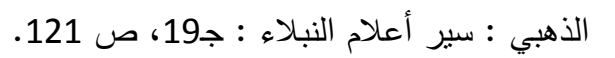

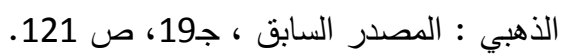

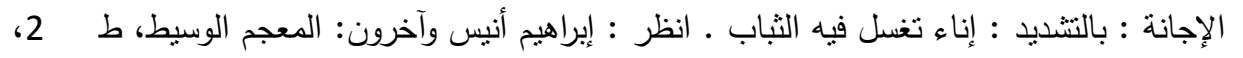

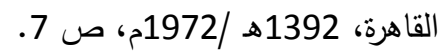

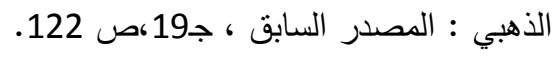

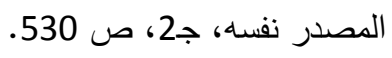

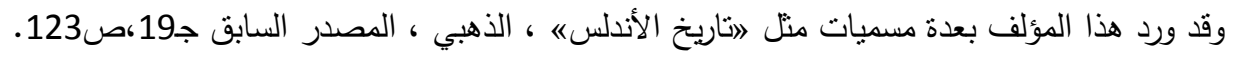

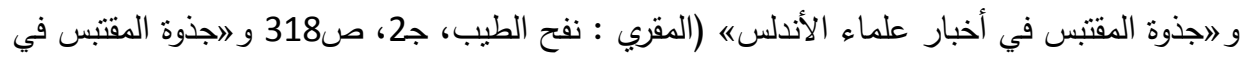

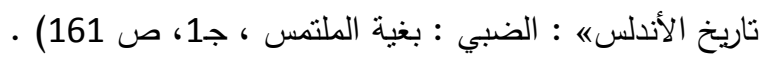

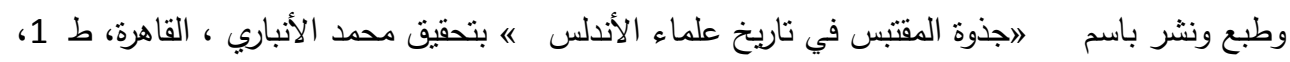

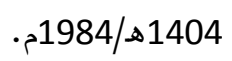

الذهبي : المصدر السابق، ج19، 1984، ص123.

يوليو 2009 
عدد من التآليف الأخرى (1) التي أمد بها المكتبة الإسلامية في فنون مختلفة من العلوم والمعارف. وقد وقف كتبه التي ألفها على أهل العلم عند وفاته (2). وكان عبدالملك بن إدربس الأزدي المعروف بابن الجزبري المتوفى سنة 394هـ من وزراء الدولة العامرية، ومن كتابها المشهورين، وأدبائها المبرزين كثير الثعر ، غزير المادة، معدود في أكابر البلغاء (3). وله ارسائل وأشعار مروية 《(4) ولم يبين لنا ابن بشكوال مواضيع تلك الرسائل غير أنه أثنار إلى براعة هذا الأديب الكاتب حيث قال عنه الولم يخلق منله كتابة وخطابة وبلاغة وشعراً وفهماً ومعرفة وبه ختم بلغاء كتاب الأندلس «"(5) وقال عنه الفتح بن خاقان (6) لاعلم من أعلام الزمان، وعين من أعيان البيانه.

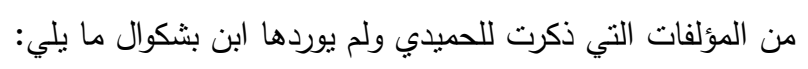

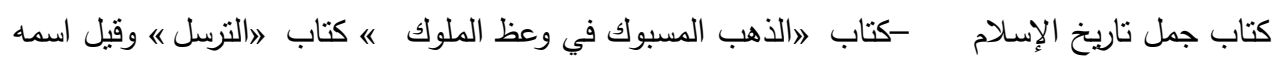

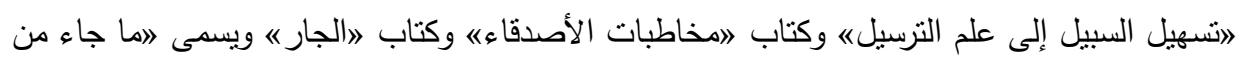

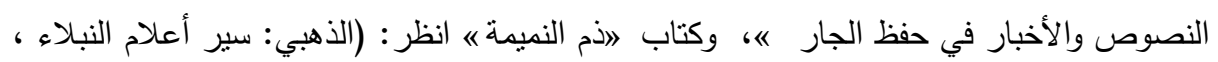

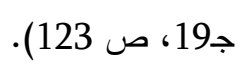

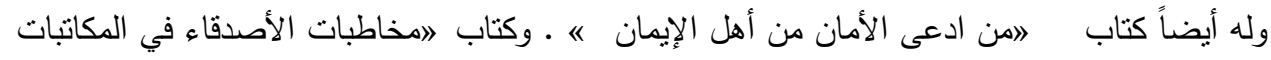

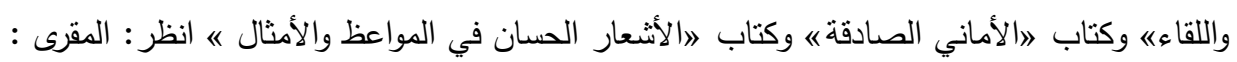

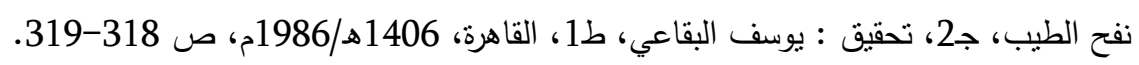

$$
\begin{aligned}
& \text { 6 المقرى ، نفح الطيب ، ج2، ص } 320 .
\end{aligned}
$$

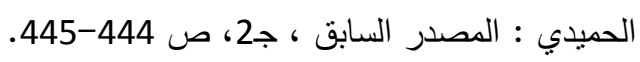

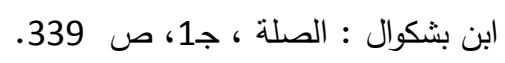

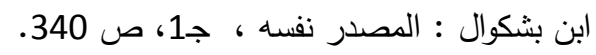

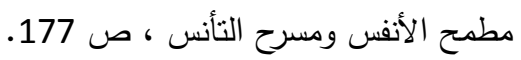

$$
\begin{aligned}
& \text { العدد الحادى و العثرون }
\end{aligned}
$$

يوليو2009 
ونختم الحديث عن دور الأزديين في التتصبف والتأليف بذكر علم آخر من أعلام الأزد في الأندلس ألا وهو : علي بن عبداله بن علي بن محمد بن يوسف الأزدي

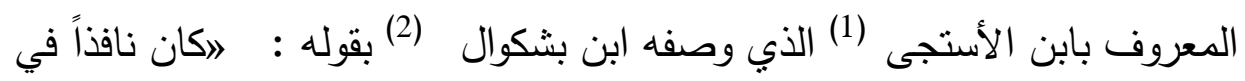

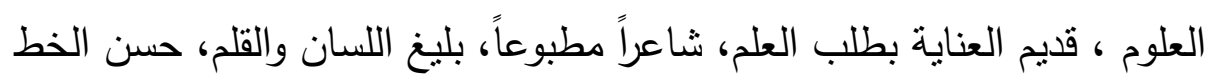

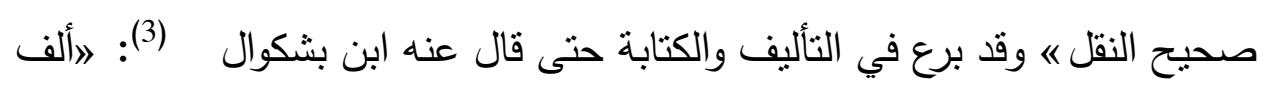

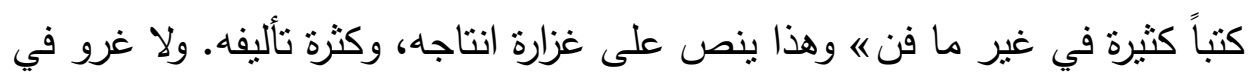

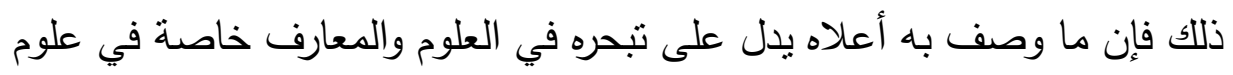

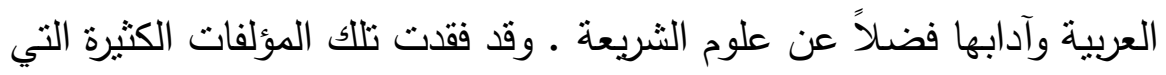

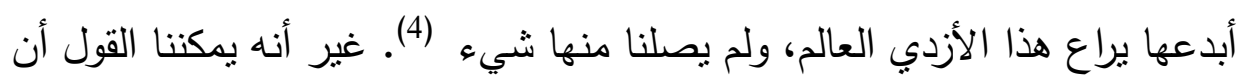
طلاب العلم المعاصرين لابن الاستجى والقريبين من عهده قد أفادوا منها . ولا شكك أن هؤلاء المؤلفين من الأزديين الذين ذكرهم ابن بشكوال وتلك المؤلفات

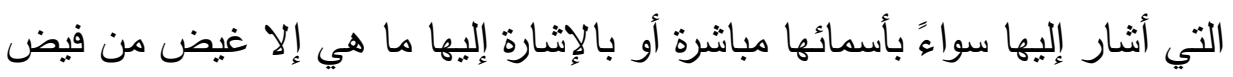

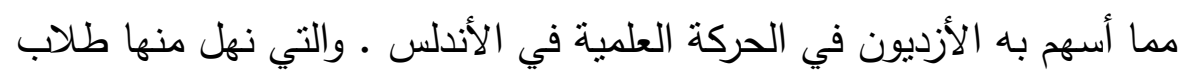
العلم في الأندلس من خلال حلقات العلم التي تدرس فيها تلك المؤلفات، كما اعتمد عليها كثير من المؤلفين الذين جاءوا من بعدهم.

(انظر عنه: الحمبي : الدصدر السابق ، ق2، ص 497.

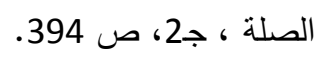

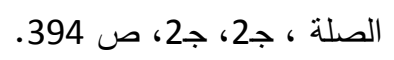

لقد جهدت في البحث عن هذه المؤلفات ومسمياتها وموضوعاتها في كل كتب التراجم التي الطعت

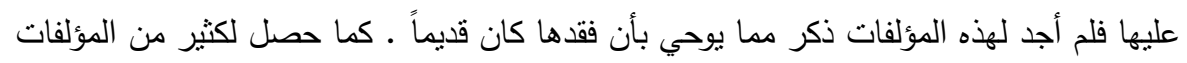




\section{دور الأزبيين في » التعليم والتدريس《}

اضطلع عدد من الأزديين بدور رائد في حركة التعليم في الأندلس ، وقد

أشنار المؤلف في درج نرجمته لعدد من الثخصيات الأزدية بدور أولئك الأعلام في التدريس والتعليم سواءً في المساجد أو حلقات العلم أو حتى في منازلهم، متصدرين لتدريس طلاب العلم ما أتقنوه من علوم، وما حصلوه من معارف، يردون عليهم ما حفظوه من مرويات وروايات، ويشرحون أمهات الكتب في مختلف الفنون، وينثرون دُر ما أبدعوه في مؤلفاتهم لمن قصدهم من طلاب العلم. ولا يكاد علم من الأعلام الأزديين الذين أوردهم المؤلف في كتابه يخلو من إثنارة إلى دور أسهم به في التعليم والتدريس والرواية في مدينته التي نشأ بها أو المدن التي استقر بها ـ فقد كان عبداله بن خلف الأزدي (ت 327هـ) إماماً لمسجد غالب في قرطبة ويدِّرس في مسجده لطلاب العلم • ولعله إلى جانب تدريس القرآن الكربم كان يدرس الحديث والفقه وكان من أبرز من روى عنه كما ذكر ابن بشكوال

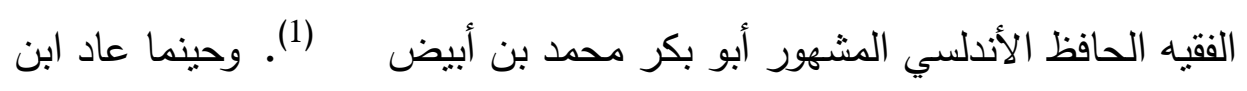
الفرضي من رحلته إلى المشرق برز في العلوم الثرعية بشكل كبير وأصبح مقصد طلاب العلم الذين كان يتكاثرون في حلقته حيث كان فقيهاً وراوية ولغوياً فصيحاً وشاعراً مبدعاً ينثر لطلابه في حلقات درسه مخزونه الرفيع في كل من هذه الفنون التي برع فيها معلماً ومؤلفاً (2).

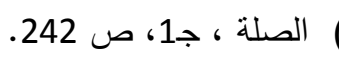

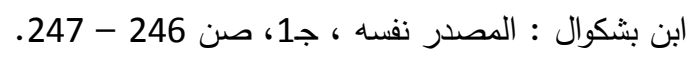

يوليو 2009 العدد الحادى و العشرون 
وكان من أبرز التلاميذ الذين تلقوا العلم على يديه أبو عمر بن عبدالبر

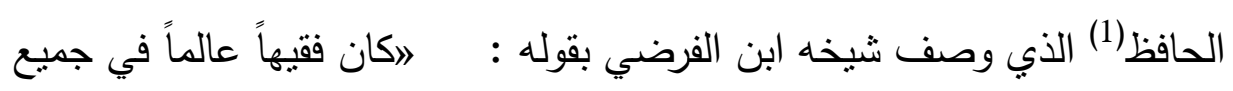

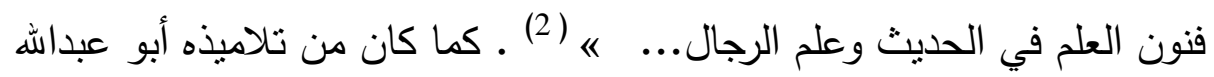

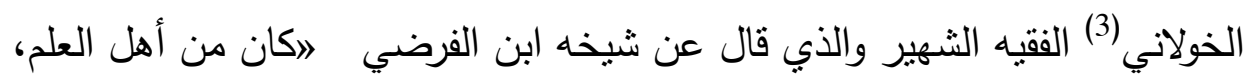
جليلاً ومقدماً في الآداب، نبيلاً مشهوراً بذلك هـ (4).

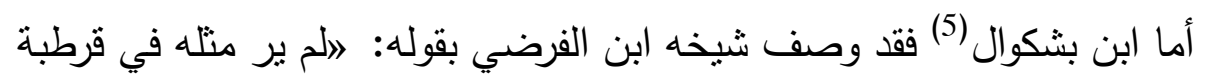

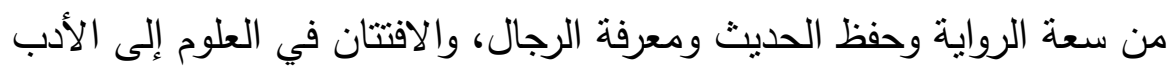
البارع والفصاحة المطبوعة.. «. ولقد كان ابن الفرضي يجمع في دروسه بين الفقه والحديث والأدب والسير وينثد طلابه بعض أثنعاره (6). وبلغ من علو كعبه في العلم وإقبال الطلاب عليه أن كلف بقراءة الكتب في عهد بني عامر (7)، وهذه المهمة التي يصدر بها تكليف مباشر من الحاكم لا يرشح

$$
\begin{aligned}
& \text { انظر أعلاه ص : نو : }
\end{aligned}
$$

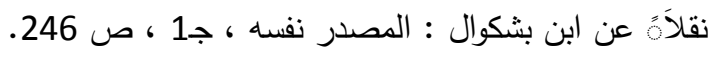

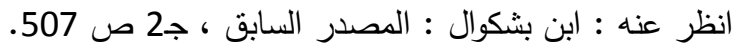

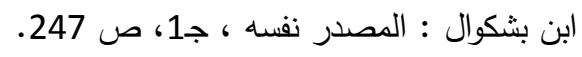

$$
\begin{aligned}
& \text { 1المصدر نفسه ، ج1، ص صن } 248 . \\
& \text { الحميدي : جذوة المقتبس ، ج1، ص صل1 396-398. }
\end{aligned}
$$

بنو عامر : ينسبون إلى الحاجب المنصور محمد بن أبي عامر حاجب الخليفة هثام المؤيد وقد أصبح

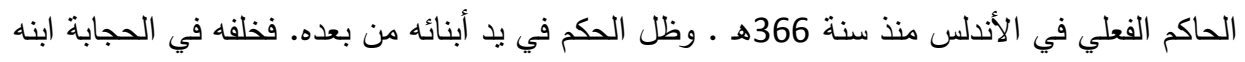

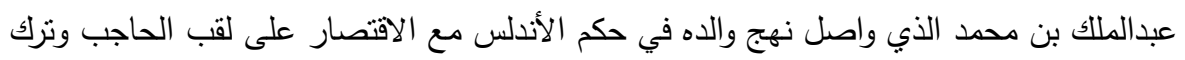

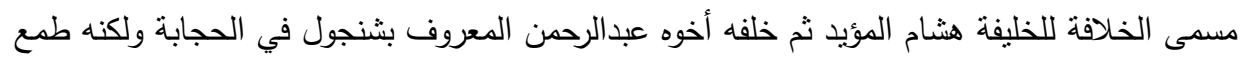

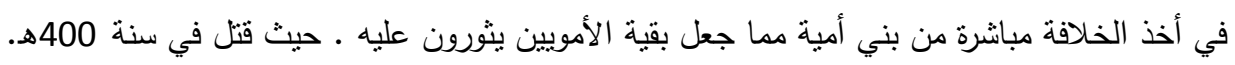
يوليو 2009 
لها إلا من كان له قدم في العلم راسخة، وخبرة في الدرس والتعليم كبيرة ومكانة مرموقة لدى الحاكم والعلماء - على حدٍ سواء-.

وكان ابنه مصعب بن عبداله الأزدي 》أديياً ومحدثاً وإخبارياً وشاعراً (1). وكان عبدالرحمن بن محمد بن أبي يزيد الأزدي (ت 410هـ) : ارجلاً أديباً حلواً

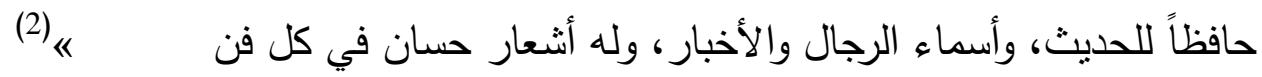
وكان بارعاً في علم الأنساب واشتهر به (3). وكان له تلاميذه وطلابه الذين يتحلقون في درسه لسماع هذه العلوم عنه (4). وكما كان له دروسه وتلاميذه في الأندلس فقد كان له أيضاً تلاميذه ودروسه في مصر التي انتقل إليها عند وقوع الفتتة في قرطبة (5). وبرع سعيد بن عبداله بن دُحيم الأزدي (ت 429هـ) في علوم اللغة العربية وآدابها بصفة عامة والنحو بصفة خاصة حيث كان : لاإماماً في كتاب سيبويه ، ذا حظ وافر من علم اللغة وشروح الأشعار وضروب الآداب والأخبار «(6) وكان له في

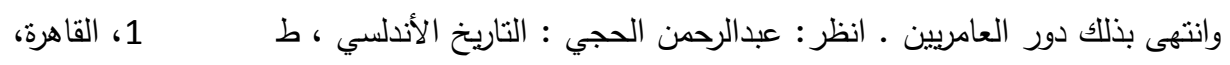

$$
\begin{aligned}
& \text { 1403هـ/1983م، ص 306-307. }
\end{aligned}
$$

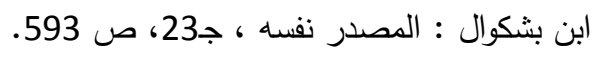$$
\text { السابق نفسه ، ج1، ص } 337
$$

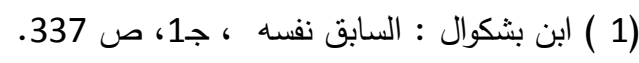

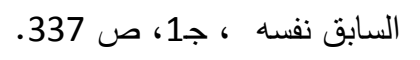

السابق نفسه ، ج1، ص 337 ، 337 .

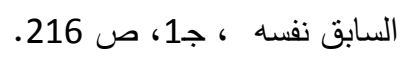

يوليو 2009 
إثبيلة أثره ودوره في نشر علوم العربية وتدريس النحو بها (1). وفي تاكرنا (2) برز معوز بن داود الأزدي (ت 431هـ) كعالم من أبرز أعلام تللك المدينة حيث كان

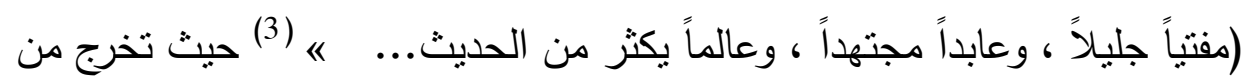
مجالس حديثه علماء بارزون وتلاميذ نجباء كان من أثهرهم القاضي يونس بن أحمد (4) ، والفقيه أبو عبدالله محمد بن عتاب (5) وغيرهم. وكان أبو إسحاق إبراهيم بن محمد الأزدي (ت 462هـ) يلقب بالمقرىء حيث كان ملماً بالقرآن وعلومه، بارزاً في علم القراءات وقد جلس لتعليم الناس وإقرائهم القراءات في قرطبة (6) وحينما توفي عالم القراءات بقرطبة أبي القاسم بن عبدالوهاب(7) حل مكانه في إقراء الناس وتعليم القراءات إبراهيم بن محمد الأزدي هذا فكان علماً في ذلك أفاد منه طلاب العلم في قرطبة بشكل كبير (8). وكان طاهر بن هشام الأزدي (ت 477هـ) من شيوخ المرية الكبار ومفتيها، وممن جلس

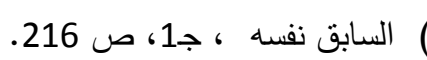

تاكرنا: مدينة منوسطة تقع بالقرب من استجة في جنوبي الأندلس (انظر : الحميري، المصدر السابق،

$$
\text { سوف بأتي الحديث عنه أدناه. : الدصدر نفسه ، ج2، ص } 591 .
$$

انظر عن ترجمته : الذهبي : سير أعلام النبلاء ، ج18، ص 328 .

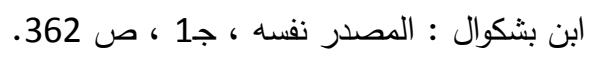

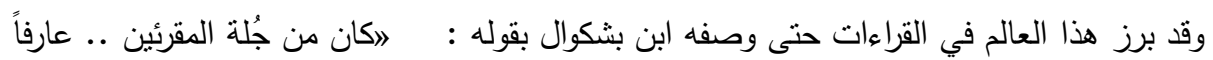
بالقراءات وطُرفها أحسن الضبط لها، وكانت الرحلة في وقته إليهه.

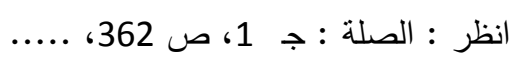

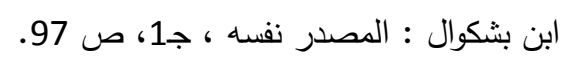

يوليو 2009

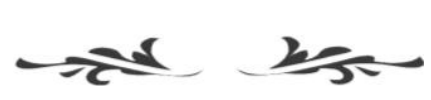

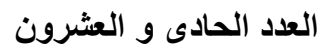


طلاب العلم بها في حلقات درسه في الحديث والمسائل بعد عودته من رحلته إلى المشرق في طلب العلم (1). وفي طليلطة ومجريط كان يونس بن أحمد الأزدي (ت 474هـ) يُدِّس في الزهد والرقائق إلى جانب الفقه والحديث (2) و اله بصر بالمسائل وتصرف في الحديث《(3) وكان -رحمه الله - "جميل المعاثرة، أحسن الناس خلقاً، وأكثرهم بشاشةه كما وصفه ابن بشكوال (4). أما الحميدي (ت 488هـ) فقد كان رأساً في علوم الشريعة وخاصة علم الحديث والرجال 》حتى قال بعض الأكابر ممن لقي الأئمة: لم تز عيناي منل أبي عبداله الحميدي في فضله ونبله ونزاهة نفسه وغزارة علمه وحرصه على نشر العلم وبثه

$$
\text { في أهلهی(5). }
$$

وقد جلس لتدريس طلاب العلم من كتابه الذي جمع فيه بين صحيحي البخاري ومسلم 》 فأخذه الناس عنه «|(6) حيث كان اإماماً في علم الحديث وعلله ومعرفة فنونه ورواته، محققاً في علم الأصول على مذهب أصحاب الحديث «(7).

$$
\begin{aligned}
& \text { ابن بشكوال : المصدر نفسه ، ج1، ص 235، ج2، ص } 619 \text { ابن } 648 \text { ، } 619
\end{aligned}
$$

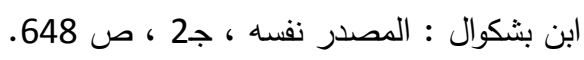

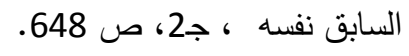

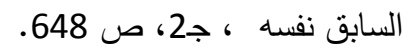

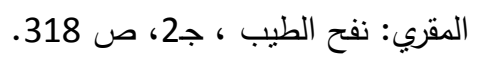

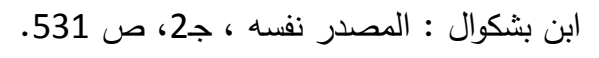

$$
\begin{aligned}
& \text { الغزي : الدصدر السابق ، ج2، ص } 318 \text { العثدال }
\end{aligned}
$$

يوليو2009 
وبما أن الحميدي كان متبحراً في علوم العربية وآدابها وعلم الرجال والسير

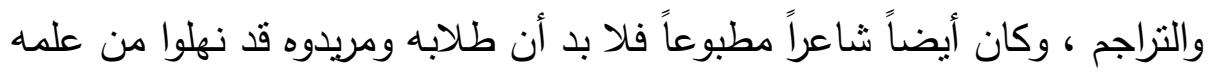
الغزير في هذه العلوم والمعارف. وتكاثر الطلاب حوله حتى وصفه الحجاري في

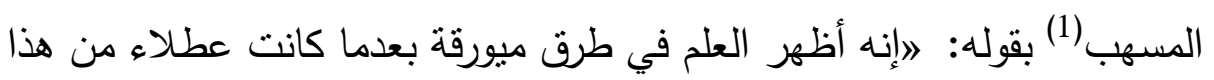

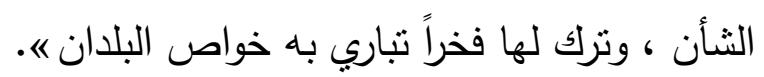
وحسب الحميدي هذا الوصف من إحياء العلم ونشره وتعليمه للطلاب في

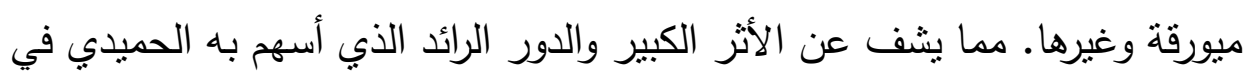
التعليم فضلاً عن التأليف - كما سبق بيانه أعلاه- . وممن أخذ طلاب العلم الأندلسيون عنهم في قرطبة والمرية خلف بن عبداله بن مدير الأزدي (ت 495هـ) حيث كان يدرس الحديث وعلوم القراءات في المسجد

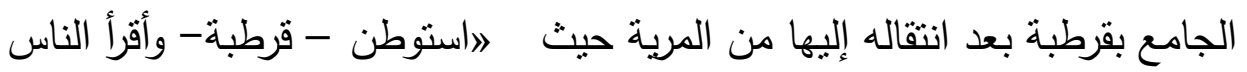

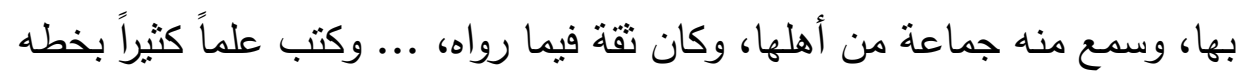
ورواهي" (2). وكان من أبرز تلاميذه محمد بن أصبغ قاضي الجماعة بقرطبة (3).

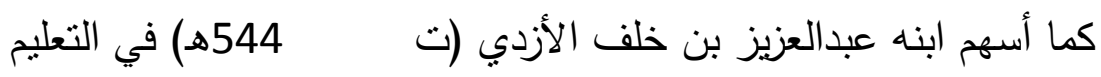

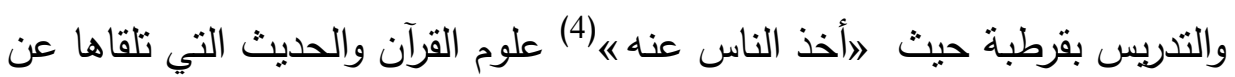
والده وكبار علماء الأندلس المعاصرين له .

$$
\begin{aligned}
& \text { نقلاً عن المقري: المصدر نفسه ، ج2، صن } 319 . \\
& \text { ابن بشكوال : الصلة ، ج1، ص } 170 . \\
& \text { سوف يأتي الحديث عنه أدناه. }
\end{aligned}
$$

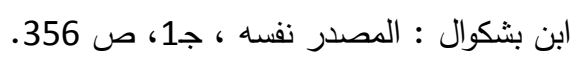

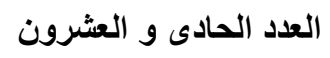$$
\text { يوليو } 2009
$$ 
وكان أصبغ بن محمد ״كبير المفتين بقرطبة «(1) وشيخ المالكية وعالمهم

بها(2) وقد "حديث وسمع الناس منه (3) وييدو أن درسه كان في جامع قرطبة حيث كان إماماً له، وقد كان من كبار فقهاء المذهب المالكي في عصره لذلك كان كبير المفتين في قرطبة ومقدماً في الثورى لدى ولاة الأمر بها ، وبلغ من منزلته في العلم، وعلو كعبه فيه أن كانت المناظرات تجري بين يديه في مجلس درسه بقرطبة(4). ولا شك أن إجراء المناظرات بين يديه دليل على علو منزلته، وقدرته العلمية الكبيرة في الفصل بين المتناظرين. وقد اضطر في آخر عمره للزوم داره وعدم الخروج إلى طلاب العلم الذين كانوا يتحلقون حوله وذلك بسبب سعاية لحقته(5) ونتج عن ذلك : اأن حُرم الناس منفعة علمه «(6) بوكان ابنه محمد بن أصبغ بن محمد الأزدي قاضي الجماعة بقرطبة (ت 536هـ)(7) قد واصل منهج والده فجلس للتدريس واسماع الحديث بقرطبة في المسجد الجامع الأنسى من قبله .. واستمر على ذلك إلى أن توفي «(8) وكان قد بلغ من العلم درجة عالية أهلته لتولي عدد كبير من المناصب في قرطبة منها قضاء الجماعة. وخطة أحكام

$$
\begin{aligned}
& \text { (5) ابن بشكوال : المصدر نفسه ، ج1، ص } 110 .
\end{aligned}
$$

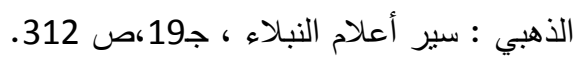

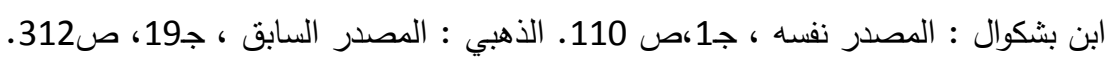

$$
\begin{aligned}
& \text { (2) ابن بشكوال : المصدر نفسه ، ج1،صند110. }
\end{aligned}
$$

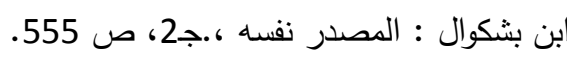

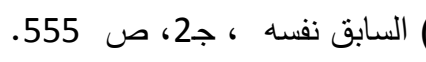

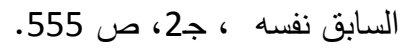

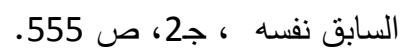

$$
\begin{aligned}
& \text { العدد الحادى و العثرون }
\end{aligned}
$$

يوليو 2009 
المظالم، والثورى وغيرها (1). وتوليته كل هذه المناصب دليل على مكانته العلمية

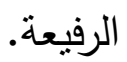

أما اسماعيل بن حمزة الأزدي المالقي فقد برع في علم أصول الديانات، وكان

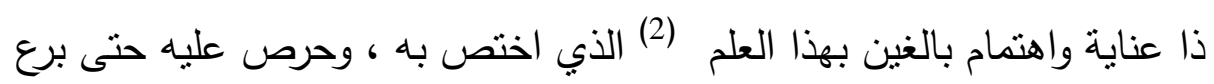

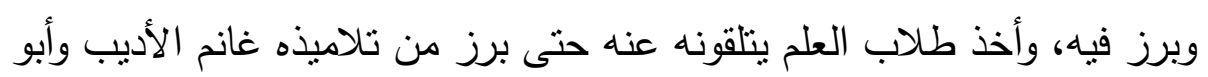

\section{الطرف الثعبي وغيرهم (3).}

الخاتمــة:

ويتنين لنا من خلال النماذج التي سقناها أعلاه الدور الكبير الذي أسهم به

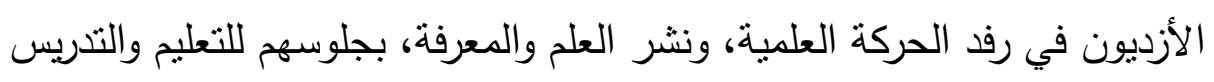
في عدد كبير من مدن الأندلس وحواضرها الكبرى منل قرطبة وانشيلية وطليطلة

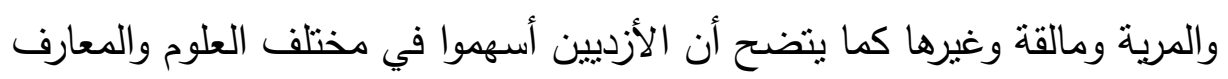

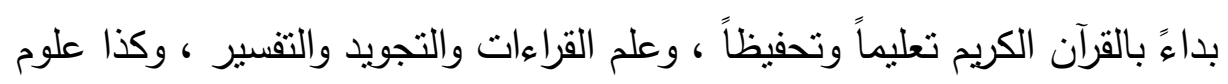

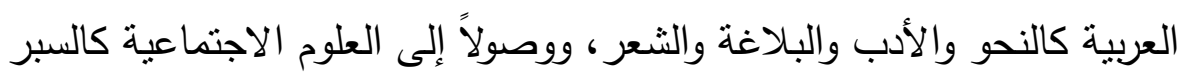

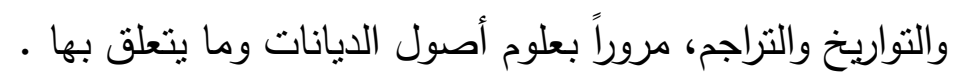

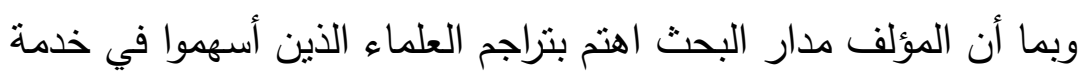
علوم الثريعة والعربية على وجه الخصوص فإنه لم يتعرض لغيرهم ممن كان له

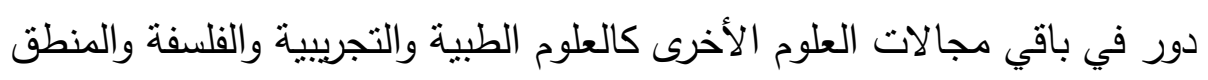

$$
\begin{aligned}
& \text { (6 الصدر السابق ، ص } 555 .
\end{aligned}
$$

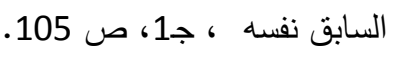

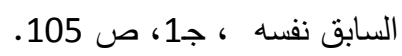

يوليو 2009

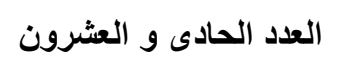


وغيرها .ولم يكتف الأزديون في رفد ودعم الحركة العلمية في الأندلس بالتأليف والتدريس وإنما أسهموا بدور بارز وظاهر في مجالات أخرى كان لها أثرها -بدون شك- في دعم الحياة العلمية في الأندلس منل إمامة الصلاة في مساجد وجوامع عدد من المدن الأندلسية. وتولى الخطبة بتلك الجوامع(1).

ولا شك أن أولئك الأئمة والخطباء قد اضطلعوا بدور لا يقل أهمية عن سابقيهم في المحافظة على الآداب العامة للمجتمع والحرص على المحافظة على الأخلاق الإسلامية الرفيعة فضلاً عن ما يقدم أولئك الأئمة والخطباء من تتقيف

وتعليم للعامة من خلال تلك المواقع التي يتولونها (2). هذا إلى جانب أولئك الأزديين الذين تولوا مهام الافتاء والقضاء في عدد من مدن الأندلس المختلفة(3).

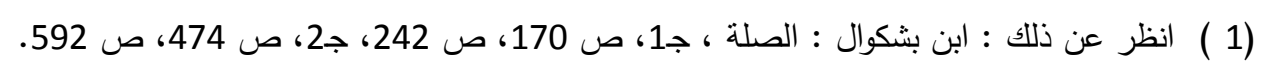

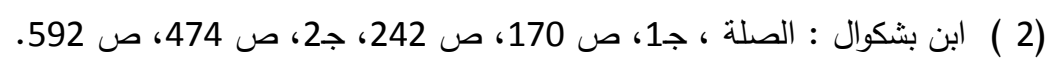

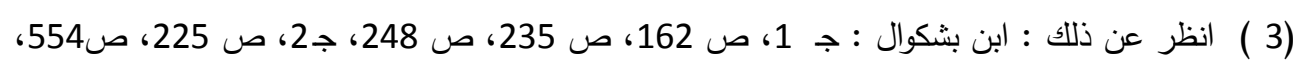

يوليو2009 ص591. 


\section{المصادر والمراجع}

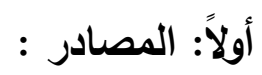

ابن بشكوال : أبو القاسم خلف بن عبدالملك (ت 578هـ/1182م) :

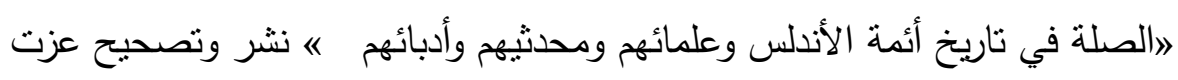

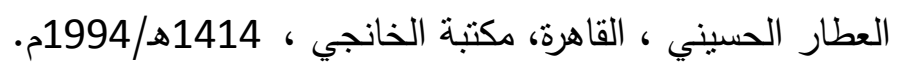
البكري : عبداله بن عبدالعزيز (ت 487هـ/1194م).

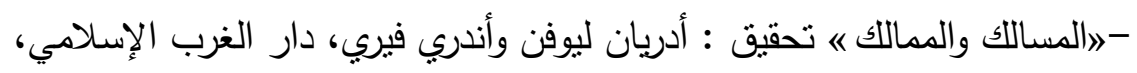
1992

$$
\text { البلاذري : أبو الحسن البلاذري (ت 279هـ/892م). }
$$

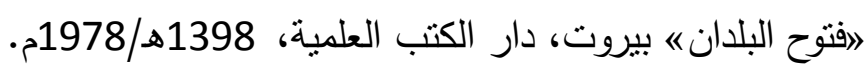

$$
\text { ابن حزم : علي بن أحمد بن سعيد (456هـ/1063م) . }
$$

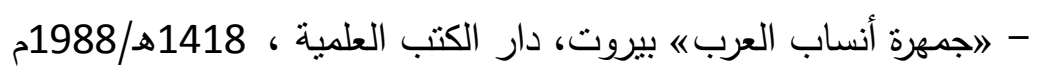
- (ارسائل ابن حزم) تحقيق : إحساب عباس ، ط1، بيروت ، 1981م. الحميدي : أبو عبداله محمد بن أبي نصر الأزدي (ت 488هـ بـ/1095م).

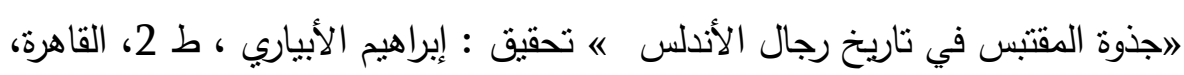

$$
\text { •1404هـ/ 1984 }
$$

$$
\text { الحميري : أبو عبداله محمد بن عبداله (ت حوالي 727هـ/1326م). }
$$

》الروض المعطار في خبر الأقطار « تحقيق : إحسان عباس، ط 2، بيروت، مكتبة

$$
\text { لبنان، 1984م. }
$$

$$
\begin{aligned}
& \text { ابن حقول : أبو القاسم بن حوقل النصيبي (ت 380هـ/990م). } \\
& \text { - صورة الأرضه ، بيروت ، مكتبة الحياة، 1979م. }
\end{aligned}
$$

يوليو 2009

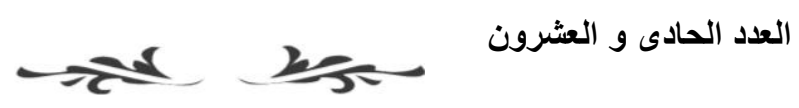


ابن الخطيب : لسان الدين أبو عبداله محمد بن عبداله (ت 776هـ/1974م).

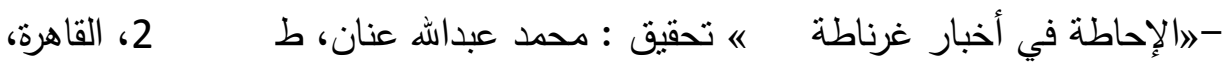
1393هـ/1973م ابن خلدون : عبدالرحمن بن خلدون (ت 808هـ/1405م). - 》تاريخ ابن خلدون ط1، بيروت ، دار الفكر، 1401هـ/1981م. ابن خلكان : أبو العباس أحمد بن محمد (ت 681هـ/1282م). - اوفيات الأعيان وأنباء أبناء الزمان " تحقيق : إحسان عباس ، بيروت، دار صادر ، 1970

$$
\text { ابن خياط : خليفة بن خياط الليتي (ت 240هـ/854م). }
$$

״تاريخ خليفة بن خياط « تحقيق : أكرم ضياء العمري، بيروت، مؤسسة الرسالة، 1397هـ 1977مـ الذهبي : شمس الدين محمد بن أحمد بن عثمان (ت 748هـ/1374م). - اتاريخ الإسلام ووفيات مشاهير الأعيان 《 تحقيق : عمر عبدالسلام تدمري، بيروت، دار الكتاب العربي ، ط1، 1407هـ /1987م. -» سير أعلام النبلاء ، تحقيق : شعيب الأرنؤوط وآخرون، ط بيروت، مؤسسة الرسالة 1412هـ/1992م.

$$
\text { الضبي : أبو جعفر أحمد بن يحيى (ت 599هـ/1202م). }
$$

-» بغية الملتمس في تاريخ رجال أهل الأندلس " تحقيق : إبراهيم الأبياري ، ط 1،

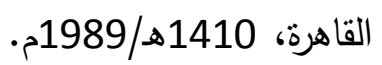
الطبري : محمد بن جرير (ت 310هـ/922هـ).

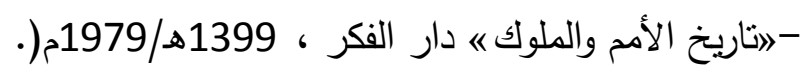
يوليو 2009 العدد الحادى و العشرون 


$$
\text { ابن عذاري : أبو العباس أحمد بن محمد (ت بعد 712هـ/1312م). }
$$

-البيان المغرب في أخبار الأندلس والغرب « تحقيق : ج. س. كولان. وليفي بروفنسال،

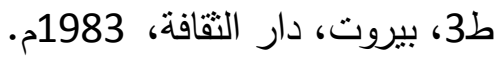

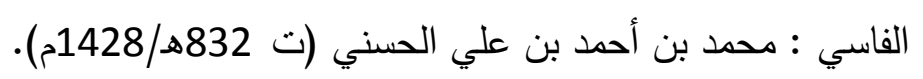

》العقد الثثين في تاريخ البلد الأمين ين نثر : محمد سرور الصبان ، القاهرة، مطبعة

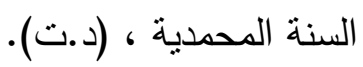
أبو الفداء: عماد الدين إسماعيل بن محمد (ت 732هـ/ 1331م). - إتاريخ أبي الفذاء《، ط1 ، بيروت ، دار الكتب العلمية، 1417هـ/1994م. - (تقويم البلدان ، بالريس ، 1850م. ابن فرحون ، إبراهيم نور الدين المالكي (ت 799هـ).

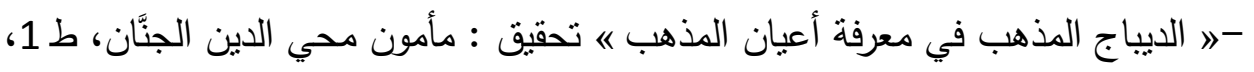
بيروت، دار الكتب العلمية، 1417هـ/1997م. ابن الفرضي : أبو الوليد عبداله بن محمد الأزدي (ت 103 403هـ/1012م).

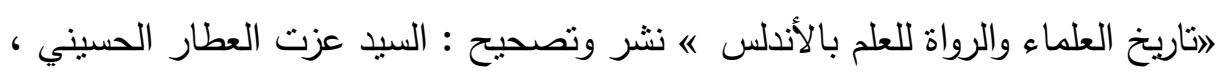
ط2، مصر ، مطبعة الدني ، 1408هـ/1988م.

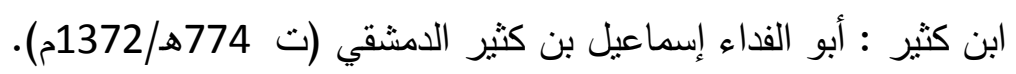
》البداية والنهاية 《) ، نحقيق : أحمد أبو ملحم وعلي نجيب عطوي وفؤاد السيد ومهدي ناصر الدين ، ط1، القاهرة، 1408هـ/1988م. المقري : شهاب الدين أحمد بن محمد التلمساني (ت 1ت 1041، 108هـ/1631م). -" نفح الطيب من غصن الأندلس الرطيب « تحقيق : يوسف البقاعي ، ط 1 1، بيروت، 1986/1406ه 


$$
\text { النجم : عمر بن فهر (885هـ/ }
$$

- إتحاف اورى بأخبار أم القرى 《 تحقيق وتقديم : فهيم شلتوت، مكة المكرمة، جامعة أم القرى ، مركز البحث العلمي وإحياء التراث الإسلامي، ط 3، 1426هـ/2005م. الوزان : الحسن بن محمد الفاسي المعروف بليون الأفريقي • -" وصف أفريقيا نترجمة : محمد حجي ومحمد الأخضر ، ط 2، دار الغرب الإسلامي، 1983

\section{ثانياً: المراجع : أن أن} أنيس : إبراهيم أنيس ورفقاه. - ا المعجم الوسيطه ط2، القاهرة، 1392 139هـ/1972م.

بالباس : ليوبولدوتورِّس.

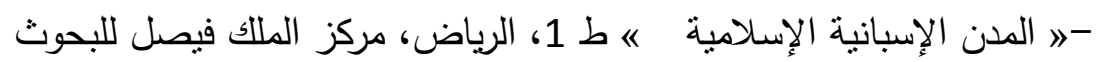

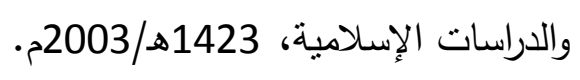

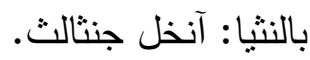

- "اريخ الفكر الأندلسي " ترجمة : حسين مؤنس ، القاهرة، (د.ت).

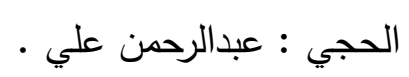

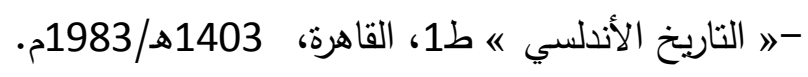

$$
\text { زيتون : محمد محمد . محن }
$$

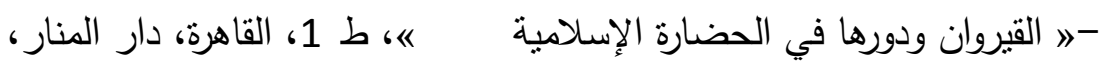

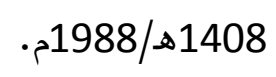

$$
\text { أبو زيد : سعيد. }
$$

-" خيران العامري صاحب مملكة المرية الأندلسية، ط 1، 1419هـ/1988م.

$$
\text { السحيباني : حمد بن صالح. }
$$

يوليو2009 
- " مصادر الحافظ ابن الفرضي في كتابه تاريخ العلماء والرواة 《 ـ مجلة جامعة أم

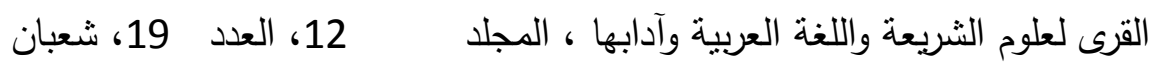
1420هـ.

السلاوي : أبو العباس أحمد بن خالد الناصري •

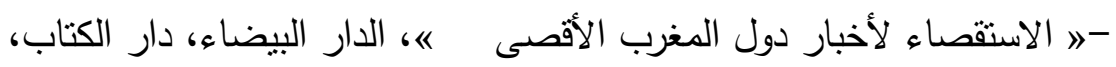

$$
\text { الثريف : خالد . 1954م. }
$$

- مدينة مالقة منذ عصر الطوائف حتى سقوطها 《 ، الرياض، مركز الملك فيصل

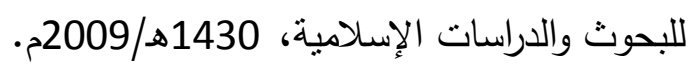

$$
\begin{aligned}
& \text { مؤنس : حسين مؤنس. }
\end{aligned}
$$

- " فجر الأندلس" جدة، الدار السعودية للنشر والتوزيع، 1405هـ/1985م.

$$
\text { نواب : عواطف محمد يوسف . }
$$

- الرحلات المغربية الأندلسية مصدر من مصادر تاريخ الحجاز في القرنين

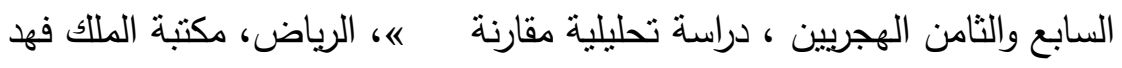
الوطنية، 1417هـ/1996م. 